Atmos. Chem. Phys., 14, 1881-1896, 2014

www.atmos-chem-phys.net/14/1881/2014/

doi:10.5194/acp-14-1881-2014

(c) Author(s) 2014. CC Attribution 3.0 License.

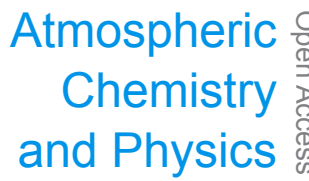

\title{
Black carbon emissions from in-use ships: a California regional assessment
}

\author{
G. M. Buffaloe ${ }^{1}$, D. A. Lack ${ }^{2,3}$, E. J. Williams ${ }^{2,3}$, D. Coffman ${ }^{4}$, K. L. Hayden ${ }^{5}$, B. M. Lerner ${ }^{2,3}$, S.-M. Li ${ }^{5}$, \\ I. Nuaaman ${ }^{5,6}$, P. Massoli ${ }^{7}$, T. B. Onasch ${ }^{7}$, P. K. Quinn ${ }^{4}$, and C. D. Cappa ${ }^{1}$ \\ ${ }^{1}$ Department of Civil and Environmental Engineering, University of California, Davis, CA 95616, USA \\ ${ }^{2}$ NOAA Earth System Research Laboratory, Boulder, CO, 80305, USA \\ ${ }^{3}$ Cooperative Institute for Research in Environmental Sciences, University of Colorado, Boulder, CO, 80305, USA \\ ${ }^{4}$ NOAA Pacific Marine Environment Laboratory, Seattle, Washington, 98115, USA \\ ${ }^{5}$ Air Quality Research Division, Environment Canada, 4905 Dufferin St., Toronto, M3H5T4, Canada \\ ${ }^{6}$ Centre for Atmospheric Chemistry, York University, 4700 Keele St., Toronto, M3J1P3, Canada \\ ${ }^{7}$ Aerodyne Research, Inc., Billerica, Massachusetts, 01821, USA
}

Correspondence to: C. D. Cappa (cdcappa@ucdavis.edu)

Received: 30 August 2013 - Published in Atmos. Chem. Phys. Discuss.: 23 September 2013

Revised: 7 January 2014 - Accepted: 15 January 2014 - Published: 18 February 2014

\begin{abstract}
Black carbon $(\mathrm{BC})$ mass emission factors $\left(\mathrm{EF}_{\mathrm{BC}}\right.$; $\mathrm{g} \mathrm{BC}(\mathrm{kg} \mathrm{fuel})^{-1}$ ) from a variety of ocean-going vessels have been determined from measurements of $\mathrm{BC}$ and carbon dioxide $\left(\mathrm{CO}_{2}\right)$ concentrations in ship plumes intercepted by the R/V Atlantis during the 2010 California Nexus (CalNex) campaign. The ships encountered were all operating within 24 nautical miles of the California coast and were utilizing relatively low sulphur fuels (average fuel sulphur content of $0.4 \%, 0.09 \%$ and $0.03 \%$ for vessels operating slow-speed, medium-speed and high-speed diesel engines, respectively). Black carbon concentrations within the plumes, from which $\mathrm{EF}_{\mathrm{BC}}$ values are determined, were measured using four independent instruments: a photoacoustic spectrometer and a particle soot absorption photometer, which measure light absorption, and a single particle soot photometer and soot particle aerosol mass spectrometer, which measure the mass concentration of refractory $\mathrm{BC}$ directly. These measurements have been used to assess the level of agreement between these different techniques for the determination of $\mathrm{BC}$ emission factors from ship plumes. Also, these measurements greatly expand upon the number of individual ships for which $\mathrm{BC}$ emission factors have been determined during real-world operation. The measured $\mathrm{EF}_{\mathrm{BC}}$ 's have been divided into vessel type categories and engine type categories, from which averages have been determined. The geometric average $\mathrm{EF}_{\mathrm{BC}}$ (excluding outliers) determined from over 71 vessels and 135
\end{abstract}

plumes encountered was $0.31 \pm 0.31 \mathrm{~g} \mathrm{BC}(\mathrm{kg} \text { fuel })^{-1}$, where the standard deviation represents the variability between individual vessels. The most frequent engine type encountered was the slow-speed diesel (SSD), and the most frequent SSD vessel type was the cargo ship sub-category. Average and median $\mathrm{EF}_{\mathrm{BC}}$ values from the SSD category are compared with previous observations from the Texas Air Quality Study (TexAQS) in 2006, during which the ships encountered were predominately operating on high-sulphur fuels (average fuel sulphur content of $1.6 \%$ ). There is a statistically significant difference between the $\mathrm{EF}_{\mathrm{BC}}$ values from CalNex and TexAQS for SSD vessels and for the cargo and tanker ship types within this engine category. The CalNex $\mathrm{EF}_{\mathrm{BC}}$ values are lower than those from TexAQS, suggesting that operation on lower sulphur fuels is associated with smaller $\mathrm{EF}_{\mathrm{BC}}$ values.

\section{Introduction}

Shipping is an important mode of transportation that has impacts on climate, air quality and human health (Fuglestvedt et al., 2009). Carbon dioxide emitted from ships is a wellknown greenhouse gas, while sulphur dioxide $\left(\mathrm{SO}_{2}\right)$ is known to have an indirect radiative cooling effect through the formation of particulate sulphate. Additionally, nitrous oxides $\left(\mathrm{NO}_{\mathrm{x}}\right)$ emissions increase ozone $\left(\mathrm{O}_{3}\right)$ production, which 
both is a greenhouse gas and contributes to the formation of particulate nitrate. Particulate matter (PM) emitted from ships, in particular $\mathrm{PM}_{2.5}$ (PM with aerodynamic diameters less than $2.5 \mu \mathrm{m}$ ), has been consistently linked to cases of pulmonary and respiratory diseases and implicated as a contributor to premature deaths from these illnesses (Corbett et al., 2007).

In order to reduce emissions of these pollutants and their impacts, regulations and incentives at state, national and international levels have targeted improvements in the quality of fuel used by ships and vessel speed reductions. Large ocean-going vessels, especially those operating slow-speed diesel (SSD) engines, commonly operate on heavy fuel oil (HFO), which typically has a very high sulphur and trace metal content. Lower sulphur fuels (LSFs) such as marine gas oil (MGO) or marine diesel oil (MDO) are usually used by smaller vessels and are substantially more refined than HFO, likely also containing lower long-chain hydrocarbons, ash and aromatics than HFO. It is possible that switching to these fuel types might also have an influence on non-sulphur particulate emissions, including black and organic carbon (Lack and Corbett, 2012). However, LSFs are typically more expensive than HFO, making HFO the preferred fuel for the shipping industry.

Examples of regulations targeting fuel quality (specifically, fuel sulphur content $\left(F_{\mathrm{S}}\right)$ ) are those introduced by the International Maritime Organization Marine Environment Protection Committee (IMO MEPC), which designates emission control areas (ECAs) and mandates global reductions in the allowable $F_{\mathrm{S}}$ for ships, with $F_{\mathrm{S}}$ reductions from $<3.5 \%$ (by weight) by 2012 to $<0.1 \%$ in 2020 (IMO, 2008). The goal of ECAs is to reduce emissions of $\mathrm{NO}_{\mathrm{x}}, \mathrm{SO}_{\mathrm{x}}$ and PM from ships (IMO, 2009). Similarly, in 2009 California began regulating the sulphur content in fuels used by ships travelling within 24 nautical miles of the California coast, lowering $F_{\mathrm{S}}$ to $\leq 1.5 \%$ (MGO) or $\leq 0.5 \%$ (MDO) in 2009 , to $\leq 1 \%$ (MGO) as of August 2012 and to $\leq 0.1 \%$ for both MGO and MDO by January 2014, with HFO usage not allowed (California Air Resources Board, 2011a). Requiring that vessels utilize lower sulphur fuels leads to dramatic reductions in the amount of sulphur emitted by ships (e.g. Lack et al., 2011). Although such $F_{\mathrm{S}}$ regulations aim to decrease the emissions of specific pollutants (e.g. $\mathrm{SO}_{2}$ ), they may also affect the formation and emission of other pollutants by influencing the combustion process and/or the need to use lubricating oil. Additionally, vessel speed reduction efforts are aimed at reducing absolute regional emissions through an increase in fuel efficiency, which reduces fuel consumption and often involves operation at lower speeds. However, the extent to which speed reductions alter emission factors (EFs, here in amount emitted per $\mathrm{kg}$ fuel consumed) that are associated with a given pollutant will depend on the type of fuel in use, the vessel type and the pollutant under consideration (Cappa et al., 2014; Petzold et al., 2011; Lack et al., 2011). The actual change in absolute emissions will depend on the interplay between the increased fuel efficiency and any alterations to the EFs that might occur with reduced-speed operation.

Black carbon (BC), which is the focus of this study, is a strongly light absorbing form of particulate matter (PM) that is produced from the incomplete combustion of fossil fuels and biomass burning. Because BC can efficiently absorb solar radiation, it can have a strong warming influence on climate, both globally and in localized areas (Bond et al., 2013; Ramanathan and Carmichael, 2008). In particular, pristine Arctic regions where shipping traffic may increase could be highly vulnerable to $\mathrm{BC}$ deposits on ice and snow, exacerbating Arctic ice melt (Flanner et al., 2007). In addition, BC, as a key component of soot, is also thought to have substantial negative consequences for health (Sydborn et al., 2001; Janssen et al., 2012; Smith et al., 2009).

Given these impacts of BC on health and the environment, current efforts exist in some regions to reduce anthropogenic emissions of BC from on-road vehicles, such as large trucks, and certain types of off-road vehicles (e.g. California Air Resources Board, 2011b). However, emissions of BC associated with marine vessels and their potential reductions are only recently being considered in detail. In particular, the IMO is focusing efforts on defining and measuring BC as well as on gathering information on the impacts of and abatement options for BC produced by ship traffic (IMO, 2011). Previous work suggests that $\mathrm{BC}$ emissions from ships make up $\sim 2 \%$ of global BC emissions, based on emission measurements and models (Lack et al., 2008a; Bond et al., 2004; Eyring et al., 2005). Measurements of emission factors for different sources, such as ships, are required for development of emission inventories, such as the US Environmental Protection Agency's NONROAD model (US EPA, 2005). Existing BC emissions inventories have been developed from a variety of data sources, but given the variety of vessel types and classes that operate in coastal areas and in the open ocean there remains a need to determine $\mathrm{BC}$ emission factors $\left(\mathrm{EF}_{\mathrm{BC}}\right)$ for a broad range of in-use ships that reflect the current shipping fleet. Further, it is important to evaluate how well different techniques for the measurement of $\mathrm{EF}_{\mathrm{BC}}$ agree.

This study utilizes measurements of $\mathrm{BC}$ made using multiple techniques to determine $\mathrm{BC}$ emission factors, in $\mathrm{g} \mathrm{BC}(\mathrm{kg} \text { fuel })^{-1}$, for 71 individual vessels. This "target-ofopportunity" study sampled BC in plumes that were encountered while the ships operated in the regulated coastal waters of California, USA, during the 2010 CalNex field campaign. The ships encountered were subject to California lowsulphur fuel requirements, and thus the vessels encountered were operating on LSFs (confirmed through in situ measurement of $\mathrm{SO}_{2}$ relative to $\mathrm{CO}_{2}$ within plumes). This is particularly important when considering the results for the larger ocean-going vessels operating SSDs encountered, as previous target-of-opportunity studies primarily observed such ships while operating on high-sulphur fuels (HSFs). The new measurements here are used to (i) add to the overall database 
of $\mathrm{EFs}$ for in-use ships; (ii) compare $\mathrm{EF}_{\mathrm{BC}}$ values as determined using different $\mathrm{BC}$ measurement techniques; (iii) investigate relationships between ship speed and $\mathrm{EF}_{\mathrm{BC}}$ to determine if such relationships can be established; and (iv) to establish whether changes in the quality of fuel utilized by ships lead to measurable differences in $\mathrm{EF}_{\mathrm{BC}}$ in the fleet average compared to previous studies.

\section{Experimental methods}

\subsection{Overview}

In May-June 2010, the R/V Atlantis travelled the California coast from San Diego to San Francisco Bay as part of the California Nexus (CalNex) campaign (Fig. 1). CalNex was a multi-institution effort aimed at improving the understanding of climate change and air quality issues, both globally and regionally in California, to support effective air quality management and climate change policy for the state (Ryerson et al., 2013). A wide variety of particle- and gas-phase measurements were made aboard the R/V Atlantis; here the focus is on measurements of BC. Over the course of the campaign, the R/V Atlantis intercepted 135 individual exhaust plumes from 71 different ships. Ambient particulate matter was sampled at a height of $18 \mathrm{~m}$ above the sea surface through a heated mast, for temperature and relative humidity stabilization, that extended $5 \mathrm{~m}$ above the containers in which the particle measurement instrumentation was housed (Bates et al., 2012). Twenty-one $1.6 \mathrm{~cm}$ outer-diameter (OD) stainless-steel tubes extended into the mast to subsample the particulate matter and distribute it to the various instruments. The sampled particles were passed through a single stage impactor with a $1 \mu \mathrm{m}$ aerodynamic diameter size cut prior to measurement. Black carbon from efficient combustion usually has a mode of $150 \mathrm{~nm}$ in mobility diameter, and so this impactor cut-off point should not subtantially affect the results. Here, particles were sampled from two of these tubes, one of which was directed to a particle soot absorption photometer (PSAP) and the second to other BC-measurement instrumentation, namely a photoacoustic spectrometer (PAS), a soot particle aerosol mass spectrometer (SP-AMS) and a single particle soot photometer (SP2). The PSAP was housed in the same container as the mast, while the other instruments were housed in a second container located directly behind the mast container. These instruments were used to quantify the concentration of BC in the sampled plumes (see Sects. 2.3.2 and 2.3.3) and, with measurements of $\mathrm{CO}_{2}$ (see Sect. 2.3.1), are used here to determine BC emission factors associated with each intercepted plume. Measurements of gas-phase $\mathrm{SO}_{2}$ were also made, from which the $\mathrm{SO}_{2}$ emission factor is determined and $F_{\mathrm{S}}$ is estimated (Williams et al., 2009a). Particles were transferred to the second container through a $2.54 \mathrm{~cm}$ OD stainless-steel tube at $30 \mathrm{lpm}$. Flow to the PAS, SP-AMS and SP2 was subsampled under nearly isokinetic conditions from this main flow, at $2.5 \mathrm{lpm}$. The gas-phase species $\left(\mathrm{CO}_{2}\right.$ and $\left.\mathrm{SO}_{2}\right)$ were sampled from a separate inlet through PFA Teflon tubing, with the inlet located $\sim 16 \mathrm{~m}$ above the sea surface and at a horizontal distance of $\sim 3 \mathrm{~m}$ from the aerosol mast in the starboard direction (Williams et al., 2009a). The gas-phase instrumentation was housed in a container separate from the PM instrumentation. Speed and other ship parameters concerning target vessels were recorded from the advanced information system (AIS) on board, an anti-collision system that can be used by ships to aid in navigation.

\subsection{Definition of black carbon}

Bond et al. (2013) define BC as "a distinct type of carbonaceous material that is formed primarily in flames, is directly emitted to the atmosphere, and has a unique combination of physical properties". Both Bond et al. (2013) and Petzold et al. (2013) describe BC as having the following physical properties: (1) strong light absorption throughout the visible spectrum, with a mass absorption coefficient (MAC) of at least $5 \mathrm{~m}^{2} \mathrm{~g}^{-1}$ at $550 \mathrm{~nm}$; (2) refractory, with vaporization temperature near $4000 \mathrm{~K}$; (3) graphitic $\mathrm{sp}^{2}$-bonded carbon with an aggregate morphology; and (4) insolubility in water and common organic solvents.

Black carbon is a component of soot and, depending on the physical property used to measure the material, is referred to as equivalent $\mathrm{BC}(\mathrm{eBC})$, refractory black carbon $(\mathrm{rBC})$, elemental carbon (EC) or light-absorbing carbon (LAC). An extensive review of the measurement methods available for EC, LAC, eBC and $\mathrm{rBC}$ will be provided in a forthcoming review (Lack et al., 2014). Relevant to this study, light absorption measurements characterize how black an ensemble of particles is and can be converted into estimates of eBC mass concentrations by dividing by the MAC. Alternatively, methods such as laser-induced incandescence characterize rBC mass more directly, although they require appropriate calibration materials. Although $\mathrm{eBC}$ and $\mathrm{rBC}$ may not be fundamentally equivalent, it is not unreasonable to think that they are nearly equivalent measures of BC (Slowik et al., 2007; Sheridan et al., 2005). For simplicity, we will therefore refer to the emission factors measured here for black carbon only as $\mathrm{EF}_{\mathrm{BC}}$, regardless of whether it is $\mathrm{EF}_{\mathrm{eBC}}$ or $\mathrm{EF}_{\mathrm{rBC}}$, although these distinctions should be kept in mind.

\subsection{Instrumentation}

\subsubsection{Carbon dioxide}

Carbon dioxide concentrations were measured using a LiCor Model LI-7000 non-dispersive infrared (NDIR) absorption instrument. Light is passed through a cavity containing the sample, where the $\mathrm{CO}_{2}$ absorbs some of the incident light. A detector at the other end of the cavity measures the remaining light and the $\mathrm{CO}_{2}$ mixing ratio is derived 

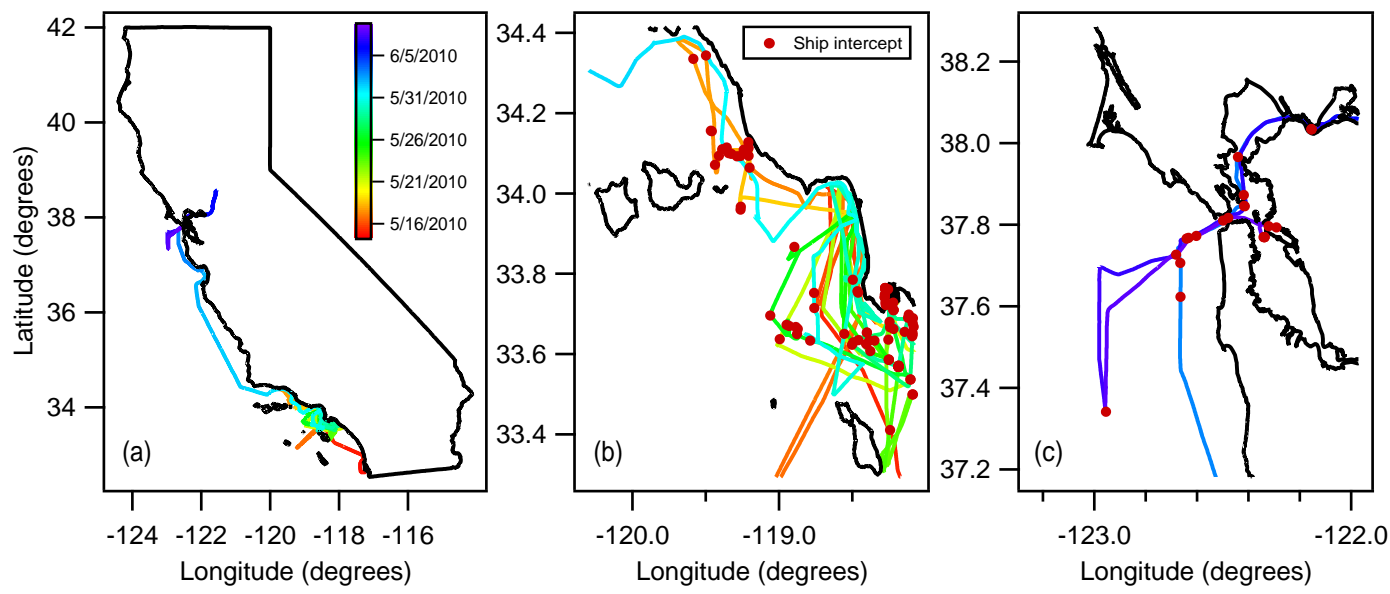

Fig. 1. Maps showing R/V Atlantis ship tracks for (a) the entire campaign, (b) southern CA near Los Angeles and (c) northern CA near San Francisco, along with locations of ship plume intercepts (b, $\mathbf{c}$ only).

from the change in intensity. The instrument acquires data at $1 \mathrm{~Hz}$, with an accuracy of $\pm 0.08 \mathrm{ppmv}$ and a precision of 0.07 ppmv (Williams et al., 2009a).

\subsubsection{Light absorption and equivalent black carbon measurements}

Light absorption coefficients for particles $\left(b_{\mathrm{abs}}\right.$, in $\mathrm{Mm}^{-1}$ ) were measured at $532 \mathrm{~nm}$ and $405 \mathrm{~nm}$ using photoacoustic absorption spectroscopy (Lack et al., 2006, 2011; Arnott et al., 1999). The PAS was calibrated by measuring the photoacoustic response to ozone at both wavelengths, and referencing the measured response to the absorption measured concurrently by cavity ring-down spectroscopy (Lack et al., 2012). The sampling time for the instrument was $\sim 2.5 \mathrm{~s}$, although the residence time in each PAS cell was closer to $20 \mathrm{~s}$ given the sample flow rate of $0.5 \mathrm{lpm}$. The instrument accuracy is estimated as $7 \%$ at $532 \mathrm{~nm}$ and $15 \%$ at $405 \mathrm{~nm}$, with a precision of $1 \mathrm{Mm}^{-1}$ (at $2.5 \mathrm{~s}$ ) during CalNex. Because the residence time of the sample in the PAS is greater than the sampling time, the measured absorption is naturally smoothed compared to the corresponding $1 \mathrm{~Hz} \mathrm{CO}$ measurements. Therefore, the $\mathrm{CO}_{2}$ data have been smoothed using a boxcar when comparing the PAS measurements with the $\mathrm{CO}_{2}$ measurements, where a boxcar calculates a moving average using an equal number of data points before and after a central data point.

A three-wavelength particle soot absorption photometer (PSAP) was also used to measure particulate light absorption at $467 \mathrm{~nm}, 530 \mathrm{~nm}$, and $660 \mathrm{~nm}$. The PSAP measures the incremental change in light attenuation through a glass fibre filter as particles are deposited onto the filter. The light absorption coefficient of the deposited particles is determined from the Beer-Lambert Law after correction for instrument response and scattering within and by particles on the filter. Further details of the specific correction scheme used are pro- vided in the Supplement. The PSAP records $b_{\text {abs }}$ at $1 \mathrm{~Hz}$, but as a running average over $\sim 30 \mathrm{~s}$, thereby smoothing the observations. Therefore, the $1 \mathrm{~Hz} \mathrm{CO}$ data have been smoothed using a boxcar when comparing to the PSAP. The uncertainty in $b_{\mathrm{abs}}$ from the PSAP is typically taken as $\pm 20 \%$ (Bond et al., 1999). This uncertainty is reasonable for particles when the non-BC-to-BC mass ratio is small (Lack et al., 2008b), which is typical for fresh ship emissions when $F_{\mathrm{S}}$ is small (Lack et al., 2011).

Assuming that black carbon is the main light-absorbing component emitted from ships, the $b_{\text {abs }}$ values can be used to determine the concentration of equivalent $\mathrm{BC}$ as follows:

$[\mathrm{eBC}]=\frac{b_{\mathrm{abs}, \lambda}}{\mathrm{MAC}_{\mathrm{BC}, \lambda}}$,

where $\mathrm{MAC}_{\mathrm{BC}}$ is the wavelength-dependent mass absorption coefficient for $\mathrm{BC}$. This conversion assumes any coatings that may be present on $\mathrm{BC}$-containing particles do not substantially increase the absorption (Bond and Bergstrom, 2006; Cappa et al., 2012) and that absorption by non-BC PM components is negligible. Both are reasonable assumptions for fresh ship emissions. During the several minutes between emission and sampling the BC particles will not have accumulated sufficient condensed material to significantly enhance absorption, and more comprehensive measurements of PM composition of ship emissions during CalNex (Cappa et al., 2014; Lack et al., 2012) indicates that the BC: TC (black carbon to total carbon) ratio for low-sulphur fuel is $\sim 0.5$. The value of $\mathrm{MAC}_{\mathrm{BC}}$ at $550 \mathrm{~nm}$ for very fresh (i.e. recently emitted) $\mathrm{BC}$ is $7.5 \pm 1.5 \mathrm{~m}^{2} \mathrm{~g}^{1}$ (Bond and Bergstrom, 2006). $\mathrm{MAC}_{\mathrm{BC}}$ values at other wavelengths are estimated as follows:

$\operatorname{MAC}_{\mathrm{BC}, \lambda}=\operatorname{MAC}_{\mathrm{BC}, 550 \mathrm{~nm}}\left(\frac{\lambda}{550}\right)^{-1}$. 


\subsubsection{Refractory black carbon measurements}

Refractory BC mass concentrations and size distributions were measured using a single particle soot photometer (SP2; Droplet Measurement Technologies, Inc.) and the soot particle aerosol mass spectrometer (SP-AMS; Aerodyne Research, Inc.). The SP2 detects thermal radiation (i.e. laserinduced incandescence) from individual black carbon particles as the particle is heated with a laser $(1064 \mathrm{~nm})$. The SP2 is highly specific to BC, where the intensity of the emitted incandescence is proportional to the incandescent mass, i.e. the black carbon mass per particle (Slowik et al., 2007; Gao et al., 2007). During CalNex, the SP2 was calibrated using size-selected fullerene soot particles, which have been shown to produce a similar response as diesel soot in the SP2 (Laborde et al., 2012a). The SP2 detected rBC particles that had rBC-only volume-equivalent diameters $\left(d_{\mathrm{p}, \mathrm{VED}, \mathrm{BC}}\right)$ between $60 \mathrm{~nm}$ and $300 \mathrm{~nm}$ (with an assumed material density of $1.8 \mathrm{~g} \mathrm{~cm}^{-3}$ ). Based on the campaign average $\mathrm{rBC}$ size distribution, it is estimated that $<7 \%$ of the $\mathrm{rBC}$ mass is contained in particles $>300 \mathrm{~nm}$. The CalNex SP2 concentrations were corrected for the observed non-unity detection efficiency (DE). The DE for this SP2 was measured to be 0.7 for particles with $d_{\mathrm{p}, \mathrm{VED}, \mathrm{BC}}$ above $\sim 100 \mathrm{~nm}$. Below $\sim 100 \mathrm{~nm}$, laboratory tests, conducted after CalNex, indicated that the DE was size-dependent, falling off steeply to where $\mathrm{DE}=0.15$ at $d_{\mathrm{p}, \mathrm{VED}, \mathrm{BC}}=60 \mathrm{~nm}$. This fall-off in the DE towards small particle sizes was previously identified by Schwarz et al. (2010) and Laborde et al. (2012b) and is the result of rapid conductive cooling of the small particles that keep them from reaching the high temperatures necessary for efficient incandescence. The SP2 rBC concentrations and size distributions have therefore been corrected using a sizedependent DE (Cappa et al., 2014). Given that the concentration of $\mathrm{rBC}$ particles with $d_{\mathrm{p}, \mathrm{VED}, \mathrm{BC}}<60 \mathrm{~nm}$ is not known, the SP2 provides a lower limit on the actual $\mathrm{rBC}$, and thus on the $\mathrm{EF}_{\mathrm{BC}}$. The SP2 operated at $1 \mathrm{~Hz}$ with an estimated accuracy of $-20 \%$ to $+100 \%$, with the lower bound being determined by uncertainty in the calibration and the upper bound being determined by both the calibration and the additional uncertainty in the concentration of particles outside of the detectable particle range.

The SP-AMS combines SP2 and standard AMS principles to quantify and characterize $\mathrm{rBC}$ (Onasch et al., 2012). In a standard AMS, particles are focused through an aerodynamic lens into a particle beam that is impacted onto a resistively heated tungsten plate at $600^{\circ} \mathrm{C}$. The non-refractory particulate components (which exclude black carbon) are vaporized, ionized at $70 \mathrm{eV}$ and detected by high-resolution particle time-of-flight mass spectrometry (HR-ToF-AMS) (DeCarlo et al., 2006). The SP-AMS adds an alternative particle vaporization method that is also sensitive to only $\mathrm{rBC}$ containing particles by thermal heating in the SP2 $1064 \mathrm{~nm}$ continuous laser. The SP-AMS can be operated with both the laser and tungsten vaporizer, or with just the laser. Dur- ing CalNex 2010 the laser-only configuration was used, and therefore only particles that contain $\mathrm{rBC}$ are vaporized and detected along with their associated non-refractory coating materials (organics, sulphates, nitrates, etc.). Unlike the SP2, the particles are heated in vacuum, and thus there is not the same fall-off in detection efficiency for small particles. In other words, the detection efficiency of particles that pass through the centre of the laser beam is independent of size. Specific $m / z$ in the mass spectrum correspond to $\mathrm{rBC}$ and can be used to quantify the $\mathrm{rBC}$ mass concentration (Onasch et al., 2012). The SP-AMS was calibrated using Regal Black particles, which have been shown to be a good surrogate for ambient BC particles (Onasch et al., 2012). The SP-AMS characterizes particles by their vacuum aerodynamic diameter $\left(d_{\mathrm{p}, \mathrm{va}}\right)$. For non-spherical fractal-like particles the specific relationship between $d_{\mathrm{p}, \mathrm{va}}$ and $d_{\mathrm{p}, \mathrm{VED}}$ is size-dependent (DeCarlo et al., 2004). It should be noted that the SP2 measures size distributions of only the rBC particle component and that $d_{\mathrm{p}, \mathrm{VED}} \geq d_{\mathrm{p}, \mathrm{VED}, \mathrm{BC}}$, while the SP-AMS $d_{\mathrm{p} \text {,va }}$ measures both the $\mathrm{rBC}$ and non-rBC material. The aerodynamic lens in use on the SP-AMS passes particles with $35 \mathrm{~nm}<d_{\mathrm{p}, \mathrm{va}}<1000 \mathrm{~nm}$ with reasonable - and well-characterized - efficiencies (Liu et al., 2007). The SPAMS collection efficiency (CE) depends importantly upon the overlap between the particle beam and laser beam, which is dependent upon the particle beam divergence, and in particular how this differs for ambient particles from the calibration particles (Onasch et al., 2012). Here, a CE for divergence of 0.4 is assumed, consistent with Cappa et al. (2013). The SP-AMS accuracy is estimated as $\pm 30 \%$ with a precision of $\pm 0.03 \mu \mathrm{g} \mathrm{m}^{-3}$. The SP-AMS was operated in "fast" mode $(1 \mathrm{~Hz})$ during only a subset of the ship plumes encountered, and thus the number of $\mathrm{EF}_{\mathrm{BC}}$ determinations is smaller than for the other instruments.

\subsection{Emission factor determination}

Mass-based emission factors ( $\mathrm{g} \mathrm{BC}$ per $\mathrm{kg}$ fuel consumed) for individual plume intercepts have been calculated from the ratio of the areas under the background-subtracted $[\mathrm{BC}]$ and $\left[\mathrm{CO}_{2}\right]$ in the plumes, $A_{\mathrm{BC}}$ (in $\mu \mathrm{g} \mathrm{m}^{-3}$ ) and $A_{\mathrm{CO}_{2}}$ (ppmv), respectively. The plume intercept method has been previously used to estimate emission factors from in-use vehicles, including ships (e.g. Lack et al., 2008c, 2009; Williams et al., 2009b). The $\mathrm{CO}_{2}$ measurements are used to estimate the fuel consumption, thus allowing for determination of $\mathrm{EF}_{\mathrm{BC}}$. This methodology inherently accounts for dilution of species within the plumes because $\mathrm{CO}_{2}$ is a conserved tracer on the minute timescales associated with emission to interception. Plumes were identified based on the relative ship positions and wind direction and speed, and by a noticeable increase in $\left[\mathrm{CO}_{2}\right], b_{\mathrm{abs}}$ or $[\mathrm{BC}]$ above background. The absolute values of $\left[\mathrm{CO}_{2}\right], b_{\mathrm{abs}}$ and $[\mathrm{BC}]$ vary from plume to plume. The length of a given plume is variable and depends mostly on the plume age and level of dilution prior to sampling. Typical 


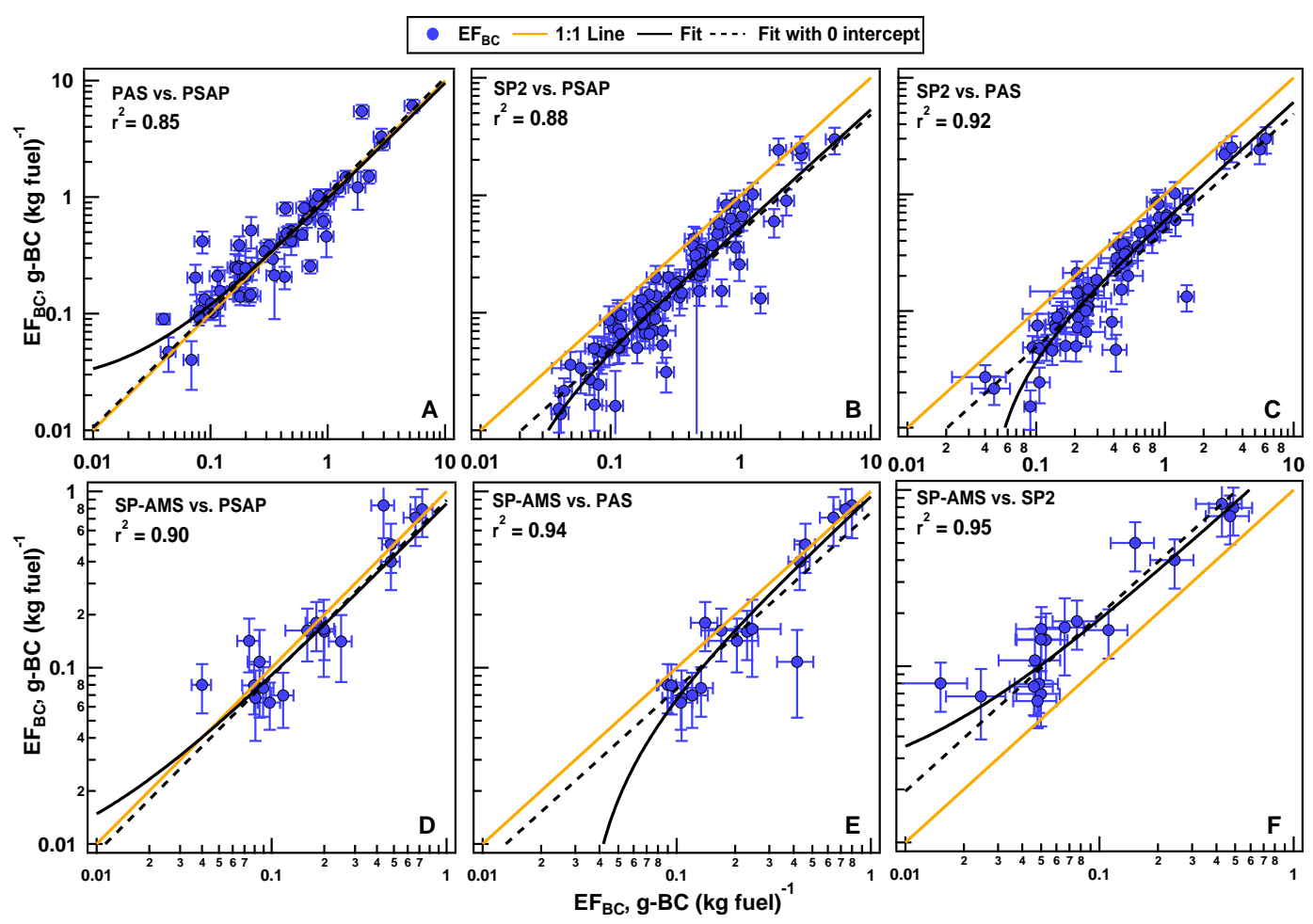

Fig. 2. Comparison of $\mathrm{EF}_{\mathrm{BC}}$ values determined using $\mathrm{BC}$ measurements from four different instruments: the PAS, PSAP, SP2 and SP-AMS. The yellow line is the 1:1 line, the dashed black line is the best fit constrained to go through the origin and the solid black line is an unconstrained fit. All fits were performed using orthogonal distance regression, with the first instrument listed in each panel being presented on the $y$ axis. Note the different scales for the figures in the top row compared with the bottom row.

plume lengths ranged from about 1 to $10 \mathrm{~min}$. Three example plumes are shown in Fig. S2. A plume-specific detection limit was established as $3 \sigma / \sqrt{N}$, where $\sigma$ is the standard deviation of the signal during the background period and $N$ is the number of points across the plume (Cappa et al., 2014). Plume-specific background concentrations were determined as the average concentration observed before and after the plume. The plume intercept method assesses only the increase in concentrations above this background level, providing a unique characterization of the emissions separate from the background.

Plume-specific $\mathrm{EF}_{\mathrm{BC}}$ values, which are traceable back to individual vessels, were determined as follows:

$\mathrm{EF}_{\mathrm{BC}}\left(\mathrm{g} \mathrm{BC}(\mathrm{kg} \text { fuel })^{-1}\right)=\frac{A_{\mathrm{BC}}}{A_{\mathrm{CO}_{2}}} f_{\text {fuel }}$,

where assuming complete combustion, $f_{\text {fuel }}$ is the fuel conversion factor $\left(1.62 \mathrm{~m}^{3} \mathrm{ppm} \mathrm{kg}^{-1}\right)$, which accounts for unit conversions for $\mathrm{CO}_{2}$ concentration in ppm to the mass concentration of carbon, and the weight fraction of carbon in the fuel (assumed to be 0.865 with a $1 \%$ uncertainty) (Lack et al., 2009a; Williams et al., 2009a). For the PAS and PSAP, where measurements were made at multiple wavelengths, weighted-average $\mathrm{EF}_{\mathrm{BC}}$ values were determined for each instrument. Instrument-specific uncertainties have been deter- mined based on the individual uncertainties in the $\mathrm{BC}$ measurement. The relationship between the determined $\mathrm{EF}_{\mathrm{BC}}$ and the absolute $A_{\mathrm{BC}}$ and $A_{\mathrm{CO}_{2}}$ values is assessed further in the Supplement (Fig. S3).

\section{Results}

\subsection{BC measurement technique comparison}

During CalNex, BC was measured using multiple techniques, namely light absorption for eBC (PAS and PSAP), laser-induced incandescence (SP2) and mass spectrometry (SP-AMS) for rBC. Some previous studies have investigated the comparability of the different measurement methods (Kondo et al., 2011; Cross et al., 2010); however such investigations were not performed for BC particles in "fresh" ship plumes. It is therefore useful to assess the extent to which these different techniques provide equivalent $\mathrm{EF}_{\mathrm{BC}}$ values, as this is influenced both by instrument accuracy and the assumption that they all measure the same thing (i.e. that $\mathrm{eBC}=\mathrm{rBC}=\mathrm{BC}$ ).

The $\mathrm{EF}_{\mathrm{BC}}$ values from these four instruments are compared in Fig. 2, where linear fits have been performed using the orthogonal distance regression method, which accounts 

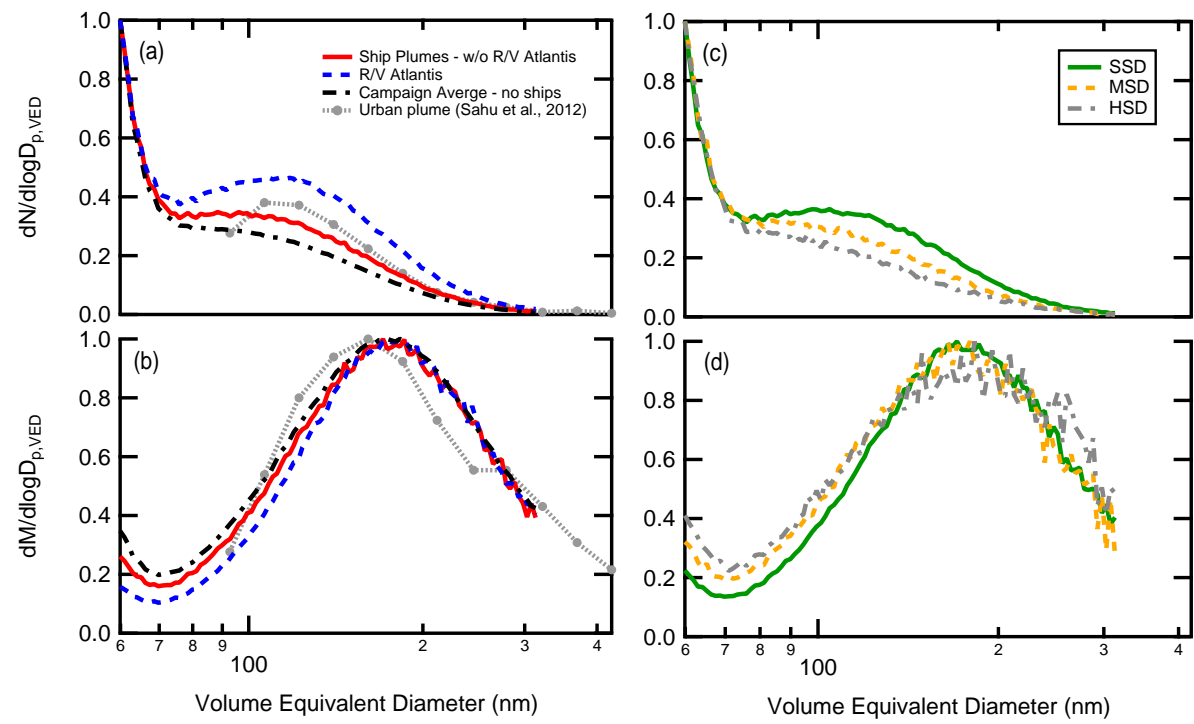

Fig. 3. Average normalized, number-weighted (a) and mass-weighted (b) size distributions for the rBC component of particles, as measured using the SP2 for all ships excluding the Atlantis (red line), the Atlantis only (dashed blue line) and the campaign average, excluding ship plumes (black dot-dashed line). A size-dependent detection efficiency has been applied (see text for details). For comparison, scaled rBC size distributions from Sahu et al. (2012) for urban plumes in CA are shown (dashed grey lines). (c) and (d) show the corresponding rBC size distributions averaged by ship engine category (and where the MSD category average excludes the Atlantis).

for uncertainties in both the $y$ and $x$ data (Table 1). Both an unconstrained fit and a fit constrained to go through the origin have been performed. Weighted Pearson's $r^{2}$ values were also calculated for each comparison, where the uncertainties of both instruments were used to weight the average $x$ and $y$ values in the calculation (see Supplement). Note that not all instruments sampled all plumes that were encountered; individual $\mathrm{EF}_{\mathrm{BC}}$ values for each ship by instrument type are given in Tables S1-S3 in the Supplement.

The $\mathrm{EF}_{\mathrm{BC}}$ values from the PAS and PSAP agreed well, with best-fit slopes of 1.06 (constrained) and 0.95 (unconstrained), and an $r^{2}=0.85$. The SP-AMS EF $\mathrm{BC}_{\mathrm{BC}}$ values also agreed well with both the PAS and PSAP, with constrained slopes of 0.89 (PSAP) and 0.76 (PAS) and unconstrained slopes of 0.85 (PSAP) and 0.96 (PAS). These slope values may indicate a low bias in the SP-AMS relative to the absorption measurements, but this cannot be established outside of the instrument uncertainties. The SP2 $\mathrm{EF}_{\mathrm{BC}}$ values are systematically lower in comparison to the other three instruments by a factor of two, with constrained slopes of 0.49 (SP2 vs. PSAP), 0.49 (SP2 vs. PAS), and 0.51 (SP2 vs. SP-AMS). As discussed above, the SP2 used during CalNex had a limited detection range $\left(60 \mathrm{~nm}<d_{\mathrm{p} \text {, VED }}<300 \mathrm{~nm}\right)$. It is therefore suggested that the lower $\mathrm{EF}_{\mathrm{BC}}$ values for the SP2 arise from a systematic negative bias of the SP2 from missed contributions of particles outside of this size range, primarily from particles with $d_{\mathrm{p}, \mathrm{VED}}<60 \mathrm{~nm}$. Log-normal fitting to rBC size distributions from the SP2 (Sect. 3.2) indicate that $<10 \%$ of the "missing" mass is contained in particles with $d_{\mathrm{p}, \mathrm{VED}}>300 \mathrm{~nm}$. This is consistent with results from a re- cent road-side study of BC emissions (Liggio et al., 2012) and with results from a case study of emissions from the R/V Miller Freeman (Cappa et al., 2014). It should be noted that such a large negative bias in the SP2 BC mass concentration is likely unique to the near-source measurements here. As the emitted plume continues to evolve, coagulation will move the smaller particles into a larger-size mode, so long as they coagulate with other rBC-containing particles. Whether coagulation is sufficient to ultimately limit the importance of this smaller mode to the total rBC measured by the SP2 and reduce this bias outside of plumes is beyond the scope of this work. Overall, the results here suggest that the two light absorption techniques (PAS and PSAP) and the mass spectrometry technique (SP-AMS) can be used to accurately determine emission factors for BC.

\section{2 rBC size distributions}

The SP2 measurements can be used to determine average number-weighted and mass-weighted size distributions of the $\mathrm{rBC}$ component of particles with $d_{\mathrm{p} \text {,VED }}$ between $60 \mathrm{~nm}$ and $300 \mathrm{~nm}$ for each individual plume. As far as we are aware, the CalNex measurements (including Cappa et al., 2014) provide the first $\mathrm{rBC}$-specific size distributions from marine vessels. Because the measurements here were made from instruments located aboard the R/V Atlantis, over the course of the campaign there were numerous encounters of individual plumes from the R/V Atlantis, many of which were freshly emitted (i.e. zero ageing). As such, we have separated out the R/V Atlantis for special consideration. 
Table 1. Linear fit coefficients from instrument comparisons, where fits were performed with the first instrument listed on the $y$ axis. The uncertainties are fit uncertainties.

\begin{tabular}{lll}
\hline Instrument Pair & Constrained Fit & Unconstrained Fit \\
\hline A: PAS vs. PSAP & $y=(1.06 \pm 0.03) x$ & $y=(0.95 \pm 0.04) x+(0.02 \pm 0.01)$ \\
B: SP2 vs. PSAP & $y=(0.49 \pm 0.02) x$ & $y=(0.54 \pm 0.03) x-(0.008 \pm 0.003)$ \\
C: SP2 vs. PAS & $y=(0.49 \pm 0.02) x$ & $y=(0.62 \pm 0.04) x-(0.03 \pm 0.01)$ \\
D: SP-AMS vs. PSAP & $y=(0.89 \pm 0.08) x$ & $y=(0.85 \pm 0.15) x-(0.006 \pm 0.017)$ \\
E: SP-AMS vs. PAS & $y=(0.76 \pm 0.07) x$ & $y=(0.96 \pm 0.17) x-(0.03 \pm 0.02)$ \\
F: SP-AMS vs. SP2 & $y=(1.95 \pm 0.21) x$ & $y=(1.66 \pm 0.32) x+(0.02 \pm 0.02)$ \\
\hline
\end{tabular}

Normalized average size distributions are shown for all the ship plumes measured by the SP2 (excluding R/V Atlantis) and for the R/V Atlantis specifically (Fig. 3). For comparison, the campaign average $\mathrm{rBC}$ size distribution, which excludes ship plumes, is also shown. To ensure that the rBC size distributions for the plumes were observable well-above background levels, only plumes with a total $\mathrm{rBC}$ number concentration $>100$ particles $\mathrm{cc}^{-1}$ or total $\mathrm{rBC}$ mass concentration $>0.1 \mu \mathrm{g} \mathrm{m}^{-3}$ were included in the average. It should be noted that the size distributions presented in Fig. 3 have been corrected for the fall -ff in the instrument sensitivity with particle size below $100 \mathrm{~nm}$. For reference the uncorrected size distributions are provided in the Supplement (Fig. S1).

Consideration of the number-weighted size distributions indicates the presence of at least two modes, one occurring between $\sim 80 \mathrm{~nm}$ and $150 \mathrm{~nm}$ and one that peaks at some $d_{\mathrm{p}, \mathrm{VED}}<60 \mathrm{~nm}$. Interestingly, the median diameter of the larger mode in the number-weighted size distributions is larger in the all-ships and the Atlantis-only plume averages than it is for the campaign average. There are only slight differences observed between the rBC size distributions observed for the vessels operating different engine types, with some suggestion of a larger contribution of small particles for HSD and MSD engines relative to SSD engines (Fig. 3). Fitting the number distributions to bimodal distributions yields for the larger mode $d_{\mathrm{p}, \mathrm{VED} \text {,med }}=92 \mathrm{~nm}, 98 \mathrm{~nm}$ and $109 \mathrm{~nm}$ for campaign average, all ships (excluding R/V Atlantis) and $\mathrm{R} / \mathrm{V}$ Atlantis only, respectively. The corresponding values for the mass-weighted distributions are $173.6 \mathrm{~nm}, 175.3 \mathrm{~nm}$ and $179.5 \mathrm{~nm}$, respectively. (The best fits yield a $d_{\mathrm{p}, \mathrm{VED} \text {,med }}$ for the smaller mode in the number-weighted distributions of $\sim 30 \mathrm{~nm}$ for all three cases, although this is quite uncertain as it involves substantial extrapolation below the measurement range.) This difference in size of the larger mode may reflect contributions to the campaign average from continental sources (e.g. on-road vehicles) to the rBC burden in the nearshore marine boundary layer. These $\mathrm{rBC}$ size distributions can be compared with that reported by Sahu et al. (2012) for $\mathrm{rBC}$ in urban (i.e. fossil-fuel-dominated) plumes over California in June 2008, who observed an rBC mode diameter slightly smaller than that observed here (Fig. 2). This is consistent with the smaller mode diameter for the campaign average distribution compared to the ship plume distributions reported here. The reason for the larger $d_{\mathrm{p}, \text { VED,med }}$ for the $\mathrm{R} / \mathrm{V}$ Atlantis compared to the other ships is not clear. However, it is noteworthy that, of all the ships sampled, the R/V Atlantis had the largest $\mathrm{EF}_{\mathrm{BC}}$, on average (Sect. 3.3).

\subsection{Emissions by engine and ship classification}

Ships encountered in this study have been classified according to their AIS vessel type codes and also classified by their engine type, similar to Lack et al. (2009a). The AIS vessel type classifications include fishing vessel, tug boat, tow boat, passenger, pilot vessel, high-speed craft (HSC), tanker, cargo and uncategorized ships. Cruise ships, which are part of the passenger category, have also been separately categorized, as has the R/V Atlantis. The three engine type classifications considered are slow-speed diesel (SSD), medium-speed diesel (MSD) and high-speed diesel (HSD). The HSD engine type includes HSC, pilot vessel, and passenger ships. The MSD engine type includes tug boats, tow boats, and fishing vessels. (The R/V Atlantis has been excluded from the MSD average and is again treated as a special case.) The SSD engine type includes cargos and tankers. The number of ships encountered of a given vessel type category ranged from 3 to 26 , and the number of vessels encountered in a given engine type category ranged from 19 to 34 .

Emissions from the ships within the various vessel and engine type categories are shown in Fig. 3 as box-and-whisker plots. In all cases, the single-ship averages were determined from only the PAS, PSAP and SP-AMS measurements because of the likely low bias in the SP2 measurements, discussed above. Because negative $\mathrm{EF}_{\mathrm{BC}}$ values are not physically reasonable, the distribution of $\mathrm{EF}_{\mathrm{BC}}$ is non-Gaussian, instead being approximately log-normal. Further, the $\mathrm{EF}_{\mathrm{BC}}$ values span nearly two orders of magnitude, so geometric statistics associated with the encountered ship plumes are reported (Fig. 4 and Table 2), which should better represent the actual sampling statistics than the corresponding arithmetic averages (Parrish et al., 1998). The geometric statistics were determined by calculating the median, average, cut average, standard deviations and boxplot ranges for $\log \left(\mathrm{EF}_{\mathrm{BC}}\right)$, and then converting back to the linear scale. $\left(\mathrm{EF}_{\mathrm{BC}}\right.$ values for each ship encountered by instrument are provided in Table S1.) The cut average is the average calculated excluding 


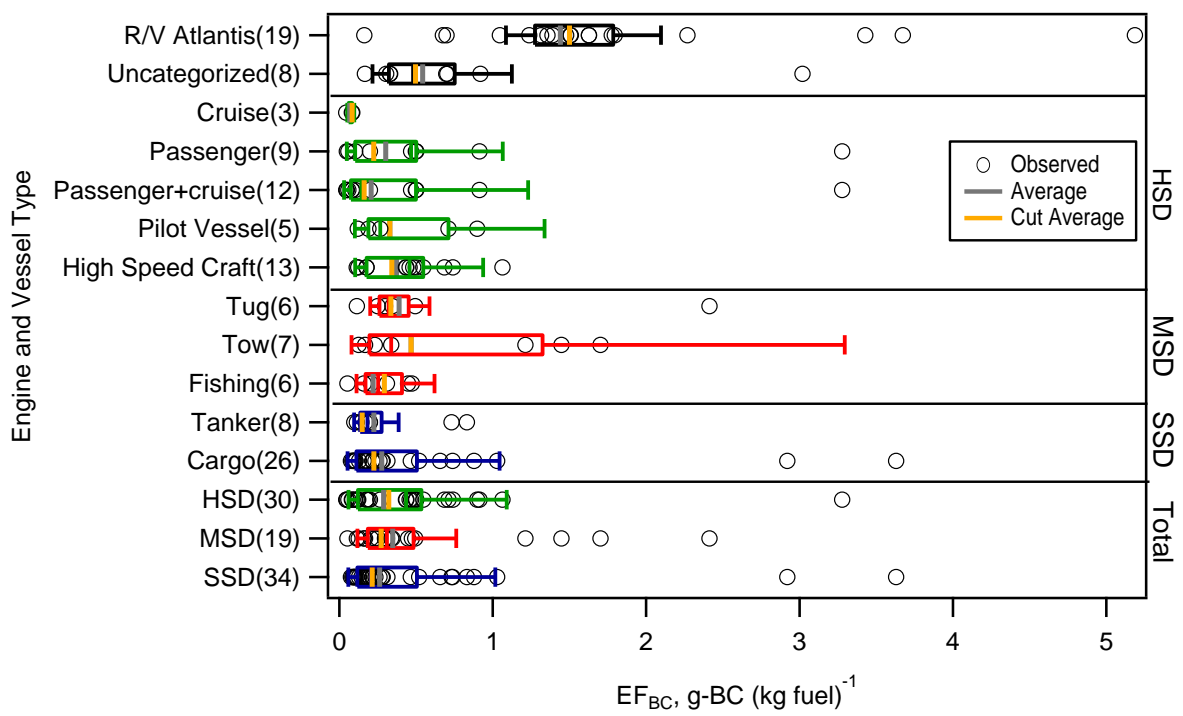

Fig. 4. Boxplots of $\mathrm{EF}_{\mathrm{BC}}$ categorized by engine type and AIS vessel type. The open circles are the weighted average $\mathrm{EF}_{\mathrm{BC}}$ determined for each vessel encounter. The boxes define the interquartile range, i.e. the middle $50 \%$ of the data. Whiskers of the boxplots are 3 times the interquartile range, and any emission factors lying outside these whiskers are considered "outliers". The median $\mathrm{EF}_{\mathrm{BC}}$ 's are the vertical lines with the same colour as the box; the geometric average $\mathrm{EF}_{\mathrm{BC}}$ 's are the vertical, grey lines; and the geometric cut-average $\mathrm{EF}_{\mathrm{BC}}$ 's are the vertical orange lines. Where the average and cut average are equal, only the cut average is seen. The number of ship encounters is listed in parentheses for each engine or vessel type.

outliers, which are defined here as the $\mathrm{EF}_{\mathrm{BC}}$ values (in logarithmic space) that fall outside $\log (3)$ times the interquartile range. The all-ships average $\mathrm{EF}_{\mathrm{BC}}$ from all the $\mathrm{BC}$ measurements (excluding the SP2), weighted by the instrumental uncertainty, was $0.31 \pm 0.31 \mathrm{~g} \mathrm{BC}(\mathrm{kg} \text { fuel })^{-1}$, and the SSD, MSD and HSD averages were $0.26 \pm 0.26,0.35 \pm 0.35$, and $0.29 \pm 0.30 \mathrm{~g} \mathrm{BC}(\mathrm{kg} \text { fuel })^{-1}$, respectively. The corresponding cut-average $\mathrm{EF}_{\mathrm{BC}}$ values are $0.21 \pm 0.16,0.27 \pm 0.12$ and $0.32 \pm 0.26 \mathrm{~g} \mathrm{BC}(\mathrm{kg} \text { fuel })^{-1}$ for SSD, MSD and HSD, respectively, and are similar to the median values (Table 2). The observed variability is a result of sampling over many individual vessels. Of all the vessel types, the tow boats have the greatest ship-to-ship variability in $\mathrm{EF}_{\mathrm{BC}}$. This variability may be influenced by having sampled ships that were either in use or that were not towing at the time of emission. The R/V Atlantis also exhibited substantial variability in its $\mathrm{EF}_{\mathrm{BC}}$ values, and additionally has an average $\mathrm{EF}_{\mathrm{BC}}$ that was much larger than that observed for most other vessels. Because sampling took place on the R/V Atlantis bow with the stacks to the rear of the sampling inlets, and because R/V Atlantis was typically oriented to sample into the wind, intercepts of plumes from R/V Atlantis typically correspond to periods of manoeuvring (e.g. changing direction). As such, the observed variability may reflect that the sampled plumes include periods where the R/V Atlantis was decelerating, accelerating or operating at steady state at the time of emission, all of which likely influence the $\mathrm{EF}_{\mathrm{BC}}$ and contribute to the observed variability. The ship category that exhibited the least variability and the smallest average $\mathrm{EF}_{\mathrm{BC}}$ was the cruise ship category. Three cruise ships were sampled in this category, with an average $\mathrm{EF}_{\mathrm{BC}}=0.07 \pm 0.02 \mathrm{~g} \mathrm{BC}(\mathrm{kg} \text { fuel })^{-1}$.

\subsubsection{Literature comparison and influence of fuel quality on $\mathbf{E F}_{\mathbf{B C}}$}

There have been a variety of measurements of $\mathrm{EF}_{\mathrm{BC}}$ reported in the literature for single vessels or single laboratory test engines. However, given that the measurements here encompass a large ensemble of different ships we primarily limit our comparison with the literature to other studies in which more than one ship or engine has been examined. Lack et al. (2009a) measured $\mathrm{EF}_{\mathrm{BC}}$ using a light absorption technique from aboard the R/V Ronald H. Brown for over 100 vessels operating in and around Galveston Bay and the Houston shipping channel during the 2006 Texas Air Quality Study/Gulf of Mexico Atmospheric Composition and Climate Study (TexAQS-GoMACCS, referred to as TexAQS in this paper). They categorized the $\mathrm{EF}_{\mathrm{BC}}$ 's of sampled ships into engine type and vessel type categories, similar to this study. An important distinction between Lack et al. (2009a) and the current study is the fuel type in use by the encountered ships. Fuel sulphur content is estimated for CalNex and TexAQS from measurements of gas-phase $\mathrm{SO}_{2}$ emission factors in the plumes under the assumption that all of the fuel sulphur is emitted as $\mathrm{SO}_{2}$ and not particulate sulphur (Williams et al., 2009a). During TexAQS the encountered ships were not required to use LSFs, and measurements of the sulphur content of the emissions indicated that the 
Table 2. Geometric average $\mathrm{EF}_{\mathrm{BC}}$ values categorized by engine type and AIS vessel type for CalNex and TexAQS, and arithmatic average $\mathrm{EF}_{\mathrm{BC}}$ values for the lower Elbe study from Diesch et al. (2013). Uncertainties are 1 standard deviation.

\begin{tabular}{|c|c|c|c|c|c|c|c|c|c|}
\hline \multirow[t]{2}{*}{ Category } & \multicolumn{2}{|c|}{ No. of Intercepts } & \multicolumn{3}{|c|}{$\begin{array}{l}\text { Average } \mathrm{EF}_{\mathrm{BC}} \\
\mathrm{g} \mathrm{BC}(\mathrm{kg} \text { fuel })^{-1}\end{array}$} & \multicolumn{2}{|c|}{$\begin{array}{c}\text { Cut Average }{ }^{\mathrm{d}} \mathrm{EF}_{\mathrm{BC}} \\
\mathrm{gBC}(\mathrm{kg} \text { fuel })^{-1}\end{array}$} & \multicolumn{2}{|c|}{$\begin{array}{l}\text { Median } \mathrm{EF}_{\mathrm{BC}} \\
\mathrm{g} \mathrm{BC}(\mathrm{kg} \text { fuel })^{-1}\end{array}$} \\
\hline & CalNex & TexAQS & CalNex & TexAQS & Lower Elbe ${ }^{f}$ & CalNex & TexAQS & CalNex & TexAQS \\
\hline $\mathrm{R} / \mathrm{V}$ Atlantis & 19 & & $1.4 \pm 1.1$ & & & $1.5 \pm 0.2$ & & 1.5 & \\
\hline Uncategorized & 8 & & $0.54 \pm 0.48$ & & & $0.50 \pm 0.24$ & & 0.48 & \\
\hline Cruise ships ${ }^{\mathrm{a}}$ & 3 & & $0.07 \pm 0.02$ & & & $0.08 \pm 0.002$ & & 0.08 & \\
\hline Passenger $^{\mathrm{a}}$ & 9 & 8 & $0.30 \pm 0.41$ & $0.32 \pm 0.20$ & & $0.22 \pm 0.25$ & $0.32 \pm 0.20$ & 0.47 & 0.29 \\
\hline Passenger+cruise & 12 & & $0.21 \pm 0.28$ & & & $0.16 \pm 0.18$ & & 0.14 & \\
\hline Pilot Vessel $^{\mathrm{a}}$ & 5 & & $0.33 \pm 0.28$ & & & $0.33 \pm 0.28$ & & 0.27 & \\
\hline High-Speed Craft ${ }^{\mathrm{a}}$ & 13 & & $0.37 \pm 0.27$ & & & $0.34 \pm 0.23$ & & 0.46 & \\
\hline Tug $^{b}$ & 6 & 54 & $0.39 \pm 0.40$ & $0.74 \pm 0.66$ & & $0.34 \pm 0.10$ & $0.84 \pm 0.53$ & 0.32 & 0.85 \\
\hline Tow ${ }^{b}$ & 7 & & $0.47 \pm 0.51$ & & & $0.47 \pm 0.51$ & & 0.34 & \\
\hline Fishing ${ }^{b}$ & 6 & & $0.22 \pm 0.18$ & & & $0.29 \pm 0.14$ & & 0.25 & \\
\hline Tanker ${ }^{\mathrm{c}}$ & 8 & 30 & $0.22 \pm 0.18$ & $0.29 \pm 0.34$ & & $0.15 \pm 0.04$ & $0.29 \pm 0.21$ & 0.18 & 0.33 \\
\hline Cargo $^{c}$ & 26 & 11 & $0.28 \pm 0.29$ & $0.46 \pm 0.31$ & & $0.22 \pm 0.18$ & $0.55 \pm 0.14$ & 0.23 & 0.48 \\
\hline HSD/Type $1^{\mathrm{i}}$ & 30 & 8 & $0.29 \pm 0.30$ & $0.32 \pm 0.20$ & $0.21 \pm 0.23$ & $0.32 \pm 0.26$ & $0.32 \pm 0.20$ & 0.44 & 0.29 \\
\hline MSD/Type $2^{\mathrm{h}}$ & 19 & 54 & $0.35 \pm 0.35$ & $0.74 \pm 0.66$ & $0.14 \pm 0.16$ & $0.27 \pm 0.12$ & $0.84 \pm 0.53$ & 0.31 & 0.85 \\
\hline SSD/Type $3^{\mathrm{g}}$ & 34 & 41 & $0.26 \pm 0.26$ & $0.33 \pm 0.36$ & $0.12 \pm 0.08$ & $0.21 \pm 0.16$ & $0.33 \pm 0.22$ & 0.21 & 0.43 \\
\hline All Ships & 91 & 103 & $0.31 \pm 0.31$ & $0.50 \pm 0.52$ & $0.15 \pm 0.17$ & $0.28 \pm 0.21$ & $0.59 \pm 0.35$ & 0.28 & 0.54 \\
\hline
\end{tabular}

${ }^{\mathrm{a}}$ Included in high-speed diesel average; ${ }^{\mathrm{b}}$ included in medium-speed diesel average; ${ }^{\mathrm{c}}$ included in slow-speed diesel average; ${ }^{\mathrm{d}}$ excluding outliers; ${ }^{\mathrm{e}}$ Lack et al. (2008, 2009);

${ }^{\mathrm{f}}$ Diesch et al. (2013); ${ }^{\mathrm{g}}$ vessels $>30000$ tons, from Diesch et al. (2013); ${ }^{\mathrm{h}}$ vessels 5000-30 000 tons, from Diesch et al. (2013); ${ }^{\mathrm{i}}$ vessels $<5000$ tons, from Diesch et al. (2013).

average $F_{\mathrm{S}}$ for SSD vessels was $1.6 \pm 0.7 \%$ (Lack and Corbett, 2012). In comparison, the average $F_{\mathrm{S}}$ for SSD vessels during CalNex was only $0.4 \pm 0.3 \%$, significantly lower than that observed during TexAQS. This observation indicates that the vessels sampled during CalNex were utilizing LSFs with $F_{\mathrm{S}}$ much lower than the regulatory limit at the time. For the HSD and MSD vessels encountered during TexAQS, which tend to use LSFs over HFO, the average $F_{\mathrm{S}}$ was $0.4 \pm 0.4 \%$ and $0.4 \pm 0.6 \%$, respectively, whereas the $F_{\mathrm{S}}$ for HSD and MSD vessels during CalNex was lower at $0.03 \pm 0.01 \%$ and $0.09 \pm 0.10 \%$, respectively. Given that the mean $F_{\mathrm{S}}$ between the two studies are substantially different, particularly for the $\mathrm{SSD}$ vessels, differences in the observed $\mathrm{EF}_{\mathrm{BC}}$ values may provide an indication of whether the change in fuel quality results in a measurable change in the ensemble $\mathrm{EF}_{\mathrm{BC}}$ values.

A direct comparison of the ship type and engine type categories from CalNex and TexAQS is presented in Fig. 5 and Table 2. Both geometric average and cut averages are reported for all of the categories ${ }^{1}$. Beginning with HSD vessels, the average and cut-average $\mathrm{EF}_{\mathrm{BC}}$ values are quite similar, with a cut average of $0.32 \pm 0.26 \mathrm{~g} \mathrm{BC}(\mathrm{kg} \mathrm{fuel})^{-1}$ for CalNex and $0.32 \pm 0.20 \mathrm{~g} \mathrm{BC}^{(\mathrm{kg} \text { fuel })^{-1}}$ for TexAQS. Although the average $F_{\mathrm{S}}$ differs between the HSD vessels sampled during TexAQS and CalNex, the low $F_{\mathrm{S}}$ in both studies suggests use of MGO or MDO, just with different levels of sulphur removed. The similarity in the average $\mathrm{EF}_{\mathrm{BC}}$ for HSD vessels may therefore reflect a negligible effect of fuel

\footnotetext{
${ }^{1}$ Lack et al. $(2008,2009)$ reported arithmetic averages, not geometric averages, which explains the difference in the TexAQS EF ${ }_{\mathrm{BC}}$ values reported here.
}

sulphur below a certain $F_{\mathrm{S}}$ limit, although this requires further study.

Considering MSD vessels, direct comparison of the vessel type averages is difficult because the MSD category from Lack et al. (2009a) was comprised entirely of tug boats, which here only made up $30 \%$ of the sampled vessels. Comparison of just the tug boat category indicates that the average $\mathrm{EF}_{\mathrm{BC}}$ values are different, and the cut averages even more so, with cut averages of $0.34 \pm 0.10 \mathrm{~g} \mathrm{BC}\left(\mathrm{kg} \mathrm{fuel}^{-1}\right)$ for CalNex and $0.84 \pm 0.53 \mathrm{~g} \mathrm{BC}\left(\mathrm{kg} \mathrm{fuel}^{-1}\right)$ for TexAQS. However, only 6 tugs were sampled during CalNex compared to 54 in TexAQS, and thus sampling statistics in this category are weak for the new measurements reported here. Also, emissions from tugs are highly dependent upon whether or not they are actively pushing or towing another vessel, making it difficult to compare this kind of vessel. Anecdotally, few tugs were observed to be actively pushing or towing during CalNex, consistent with an overall lower $\mathrm{EF}_{\mathrm{BC}}$ for this ship type. Also, the tug boats were generally seen in the Los Angeles and Long Beach harbours, where it was difficult to identify individual plumes.

Turning to the SSD category, the difference in $F_{\mathrm{S}}$ was substantial between the two studies and indicates the use of very different fuel types (i.e. MGO/MDO vs. HFO). For this category, $\mathrm{EF}_{\mathrm{BC}}$ values for CalNex ships are lower than those from TexAQS, both for the geometric average and cut average (Table 2). The difference is more apparent in the cut average, with $\mathrm{EF}_{\mathrm{BC}}=0.21 \pm 0.16 \mathrm{~g} \mathrm{BC}(\mathrm{kg} \text { fuel })^{-1}$ for CalNex and $0.33 \pm 0.22 \mathrm{~g} \mathrm{BC}(\mathrm{kg} \text { fuel })^{-1}$ for TexAQS. The $p$ value from a two-sample $t$ test was 0.019 for the log-transformed 


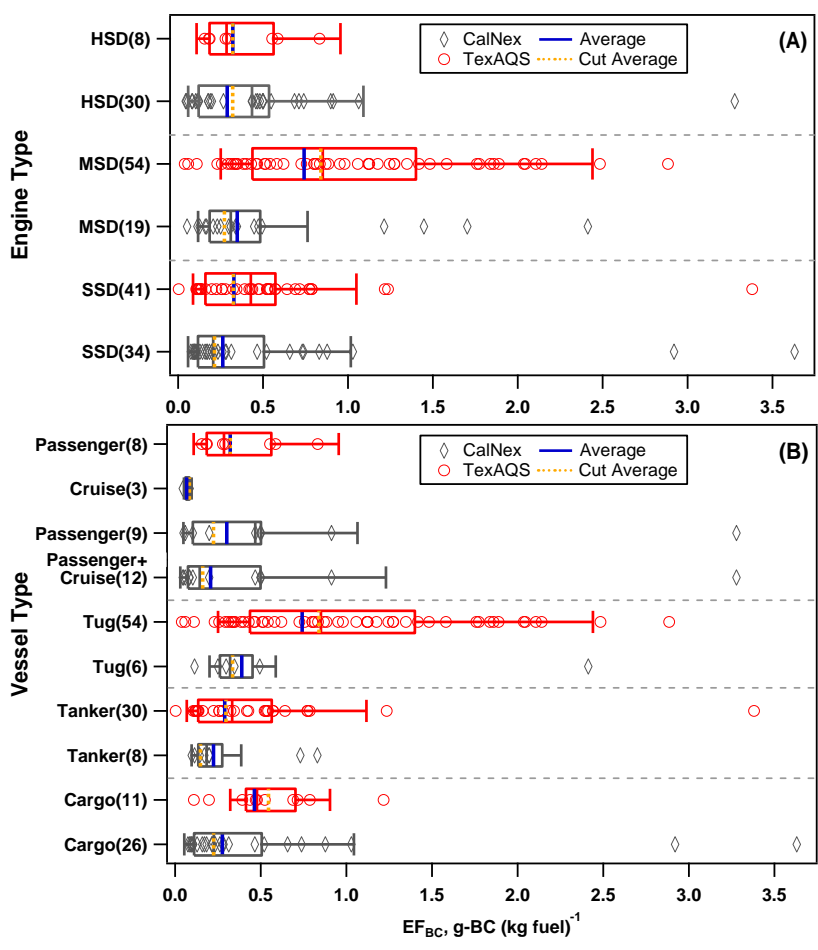

Fig. 5. Box-and-whisker plot comparing black carbon emission factors by (A) engine type and (B) vessel type from the CalNex (grey) and TexAQS (red) campaigns. The open symbols are the weightedaverage $\mathrm{EF}_{\mathrm{BC}}$ determined for each vessel encounter. The median $\mathrm{EF}_{\mathrm{BC}}$ 's are the vertical lines with the same colour as the box, the geometric average $\mathrm{EF}_{\mathrm{BC}}$ 's for a given category are indicated by the vertical blue lines, and the geometric cut-average $\mathrm{EF}_{\mathrm{BC}}$ 's are indicated by the orange lines. Where the average and cut average are equal only the cut average is seen, and where the median and average are equal only the median is seen.

SSD cut $\mathrm{EF}_{\mathrm{BC}}$ values between the two studies. This demonstrates that the TexAQS SSD $\mathrm{EF}_{\mathrm{BC}}$ and the CalNex SSD $\mathrm{EF}_{\mathrm{BC}}$ are different at a 0.05 level of significance. Tanker and cargo ships made up the majority of the sampled SSD vessels in both studies, but the fraction of each differed, with a tanker fraction of $21 \%$ for CalNex vs. $73 \%$ for TexAQS. This is a potentially important difference since Lack et al. (2009) found that $\mathrm{EF}_{\mathrm{BC}}$ for tankers was slightly lower than that for cargos, and thus differences in sampling statistics could affect the comparison. However, direct comparison of the tanker and cargo categories individually indicates even larger differences, with both the average and cut-average values from CalNex for both ship types being smaller than those from TexAQS. The $p$ values from two-sample $t$ tests of the log-transformed $\mathrm{EF}_{\mathrm{BC}}$ for tankers and cargo ships are 0.001 and $4.2 \times 10^{-5}$, respectively, demonstrating that the $\mathrm{EF}_{\mathrm{BC}}$ values for these vessel classes are different at the 0.01 level of significance. Taken together, these results for SSD vessels strongly suggest that the change in fuel quality, characterized by the decrease in $F_{\mathrm{S}}$, led to a decrease in the $\mathrm{EF}_{\mathrm{BC}}$.
This result is consistent with Lack et al. (2011), who sampled emissions from a single vessel, the R/V Margrethe Maersk, a commercial in-use cargo vessel, as it transitioned its fuel from HFO $\left(F_{\mathrm{S}}=3.15 \%\right)$ to $\mathrm{MGO}\left(F_{\mathrm{S}}=0.07 \%\right)$ while concurrently slowing from 22 knots to 12 knots. They observed a decrease in $\mathrm{EF}_{\mathrm{BC}}$ of $41 \%$ after the fuel switch. Since the R/V Margrethe Maersk was simultaneously changing speed and fuel type, this decrease in $\mathrm{EF}_{\mathrm{BC}}$ cannot be definitively attributed to the change in fuel. However, given the results here, the change in fuel quality seems likely to be the primary governing factor for the change in $\mathrm{EF}_{\mathrm{BC}}$.

Our conclusion regarding the influence of fuel quality on $\mathrm{EF}_{\mathrm{BC}}$ is also consistent with results from Deisch et al. (2013), who performed stationary measurements of emissions from ships passing by their site along the lower Elbe in Germany, travelling to and from the Port of Hamburg. Their field site is located in a sulphur emission control area (SECA) region, and the average derived $F_{\mathrm{S}}$ was $0.4 \pm 0.3 \%$ for all ships and $0.55 \pm 0.2 \%$ for larger vessels called "Type 3", with gross tonnage $>30000$, and most likely comprised of SSD vessels including cargos and tankers. Given the above discussion, it is expected that Diesch et al. (2013) would have observed $\mathrm{EF}_{\mathrm{BC}}$ values lower than those from TexAQS and reasonably similar to those observed here. Their all-ships average $^{2} \mathrm{EF}_{\mathrm{BC}}$ was $0.15 \pm 0.17 \mathrm{gBC}(\mathrm{kg} \text { fuel })^{-1}$ and their Type 3 average was $\mathrm{EF}_{\mathrm{BC}}=0.12 \pm 0.14 \mathrm{gBC}(\mathrm{kg} \text { fuel })^{-1}$. Both are somewhat smaller than the SSD average and cut average here $\left(0.26 \mathrm{~g} \mathrm{BC}(\mathrm{kg} \text { fuel })^{-1}\right.$ and $0.21 \mathrm{~g} \mathrm{BC}(\mathrm{kg} \text { fuel })^{-1}$, respectively). However, most importantly, the Type 3 average from Diesch et al. (2013) is substantially smaller than the TexAQS SSD averages (Table 2). One possible reason for the lower average $\mathrm{EF}_{\mathrm{BC}}$ from Diesch et al. (2013) compared to the CalNex averages could be that the absorption measurements they used had substantially lower time resolution compared to their $\mathrm{CO}_{2}$ measurements, $1 \mathrm{~min}$ vs. $1 \mathrm{~s}$, which presents challenges in determining EFs from plumes that often last only a few minutes. However, the difference may also reflect real differences in the measured $\mathrm{EF}_{\mathrm{BC}}$ values.

A few other single vessel or test-rig studies exist that have examined the influence of changing fuel quality on $\mathrm{EF}_{\mathrm{BC}}$. Petzold et al. (2011) evaluated a $400 \mathrm{~kW}$ single-cylinder test engine while operating on $\mathrm{HFO}\left(F_{\mathrm{S}}=2.2 \%\right)$, MGO $\left(F_{\mathrm{S}} \leq 0.1 \%\right)$ or a variety of LSF biofuels. They measured both $\mathrm{BC}$ and elemental carbon (EC) emissions. (EC is commonly considered equivalent to $\mathrm{BC}$, although the measurement methods differ substantially; Petzold et al., 2013.) They observed $\mathrm{EF}_{\mathrm{BC}}$ values that were lower by a factor of $\sim 2.5-$ 7 for LSF operation compared with HFO, consistent with the results here. The $\mathrm{EF}_{\mathrm{EC}}$ results were not as clear cut, with most, but not all, $\mathrm{EF}_{\mathrm{EC}}$ values lower for $\mathrm{LSF}$ operation and a greater dependence on the particular fuel considered

\footnotetext{
${ }^{2}$ The averages from Diesch et al. (2013) are arithmetic averages, not geometric averages.
} 
compared with their $\mathrm{EF}_{\mathrm{BC}}$ (Petzold et al., 2011). Sarvi et al. (2008) compared the emissions from a medium-speed diesel test engine operating in propulsion mode on HFO or light fuel oil (LFO, a lower sulphur fuel), using measurements of the "filter smoke number" (FSN) as a BC proxy. They found that the $\mathrm{EF}_{\mathrm{FSN}}$ was generally independent of the fuel type, with $\mathrm{EF}_{\mathrm{FSN}}$ slightly lower for operation on LFO than on HFO under higher engine loads, but the opposite true at lower engine loads (Sarvi et al., 2008). However, it is not clear how good a proxy FSN is for BC under conditions where the amount of non-BC material (e.g. particulate sulphate and organic matter) varies substantially, which is the case in their study. Finally, Khan et al. (2012) measured $\mathrm{EF}_{\mathrm{EC}}$ for a single SSD vessel operating on HFO or MGO. After converting their reported EFs from $\mathrm{g}$-EC $\mathrm{kW}^{-1} \mathrm{~h}^{-1}$ to $\mathrm{g}$ $\mathrm{EC}\left(\mathrm{kg}\right.$ fuel) ${ }^{-1}$ (using the reported $\mathrm{CO}_{2}$ emissions), the arithmetic average $\mathrm{EF}_{\mathrm{EC}}$ values for $\mathrm{HFO}$ and MGO operation were $0.028 \mathrm{~g}-\mathrm{EC}(\mathrm{kg} \text { fuel })^{-1}$ and $0.013 \mathrm{~g}-\mathrm{EC}(\mathrm{kg} \text { fuel })^{-1}$, respectively, consistent with the CalNex-TexAQS comparison. An even larger difference is observed if only the EFs reported at the same engine load are considered $(0.042$ vs. $0.016 \mathrm{~g}$ $\left.\mathrm{EC}(\mathrm{kg} \text { fuel })^{-1}\right)$.

The results reported here are in contrast to recent conclusions made by the International Council on Combustion Engines (CIMAC). Their report, which cites unpublished and non-peer-reviewed work as their primary source, concludes that changing from HFO to distillate fuels will not typically result in reduced $\mathrm{BC}$ emissions and might, in fact, lead to an increase in $\mathrm{EF}_{\mathrm{BC}}$ (CIMAC, 2012). They also cite as support for their conclusions results from Lack et al. (2008a, 2009a), who found a minimal dependence on fuel type on $\mathrm{EF}_{\mathrm{BC}}$. However, the Lack et al. (2008a, 2009a) results were based primarily on comparison of their observed LSF $\left(F_{\mathrm{S}}<0.5 \%\right)$ $\mathrm{EF}_{\mathrm{BC}}$ values, which were primarily for MSD tug boats, to their observed higher fuel sulphur $\mathrm{EF}_{\mathrm{BC}}$ values, which were primarily SSD vessels. As discussed above, the activities of tugs may lead to particularly high $\mathrm{EF}_{\mathrm{BC}}$ values, making it difficult to assess the influence of fuel quality when comparing across engine/vessel type classes if tugs are included. The current study, which compares similar vessel types operating on different fuels, and much of the literature using single ships or engines (Lack et al., 2011; Petzold et al., 2011; Khan et al., 2012), indicate that the CIMAC conclusions may be in error and that switching to distillate fuels may indeed facilitate reduction in $\mathrm{BC}$ emissions.

\subsubsection{Influence of engine load}

The influence of engine load, or vessel speed, on the observed $\mathrm{EF}_{\mathrm{BC}}$ values has been investigated for the ensemble measurements here. The speeds of the encountered ships at the time of plume emissions were recorded from the AIS. Ships that have zero speed were typically anchored offshore, not at harbour, which is important since at many California ports ships at harbour operate on shore power, which would lead to a reduction in emissions. Engine load was estimated for each ship from the measured speeds according to the propeller law, which applies to ships operating fixed-pitch propellers, and is given as

$$
F_{\text {load }}(\%)=100 \cdot\left(\frac{u_{\text {meas }}}{u_{\text {max }}}\right)^{3} \text {, }
$$

where $u_{\text {meas }}$ is the actual vessel speed and $u_{\max }$ the estimated maximum speed as determined by looking up the maximum vessel speed for each ship from http://www.marinetraffic. com.

Figure 6 shows the $\mathrm{EF}_{\mathrm{BC}}$ for each plume plotted against the estimated engine load. No overall trend is discernible for the data set as a whole across all ship types, likely as a result of ship-to-ship variability and the fact that ship speed by itself does not indicate whether a vessel is travelling at a steady speed, accelerating or decelerating. The relationship between engine load and emission factor is likely confounded by the specific type of engine, engine tuning, age, and possibly fuel quality. There is, however, some indication that $\mathrm{EF}_{\mathrm{BC}}$ decreases with increasing engine load for cargo ships specifically. It should be noted that $19 \%$ of the intercepts in this category are for a single ship, the R/V Margrethe Maersk, which was also reported on by Lack et al. (2011) and sampled multiple times. However, the intercepts here all occurred after R/V Margrethe Maersk had fully switched to operate on LSF. There is some indication of an increase in $\mathrm{EF}_{\mathrm{BC}}$ with speed for the fishing vessel class, although this category consists of only one ship sampled multiple times and is actually a research fishing vessel, as discussed further in Cappa et al. (2013). The $\mathrm{EF}_{\mathrm{BC}}$ values for the R/V Atlantis do not show any clear dependence on engine load/vessel speed, which likely reflects that some of the sampled plumes correspond to periods of deceleration, some to acceleration and some to steady-state operation at the time of emission, thus confounding any clear relationship between speed and emission. The $\mathrm{EF}_{\mathrm{BC}}$ values for the other vessel classes seem most consistent with a negligible dependence on engine load/vessel speed, although again the scatter is large.

The difficulty in elucidating a clear relationship between engine load/vessel speed and $\mathrm{EF}_{\mathrm{BC}}$ from the ensemble measurements is consistent with Lack et al. (2008a), who observed a great deal of scatter in their ensemble measurements, again most likely a reflection of the ship-to-ship variability (and in their case the large number of tugs in the MSD category). It may be that single-ship (or -engine) studies, are able to do a better job of discerning possible trends between $\mathrm{EF}_{\mathrm{BC}}$ and engine load, though even then there remains a wide range of results. However, most single-ship studies find that $\mathrm{EF}_{\mathrm{BC}}$ generally decreases or remains relatively constant as engine load increases (Cappa et al., 2014). 


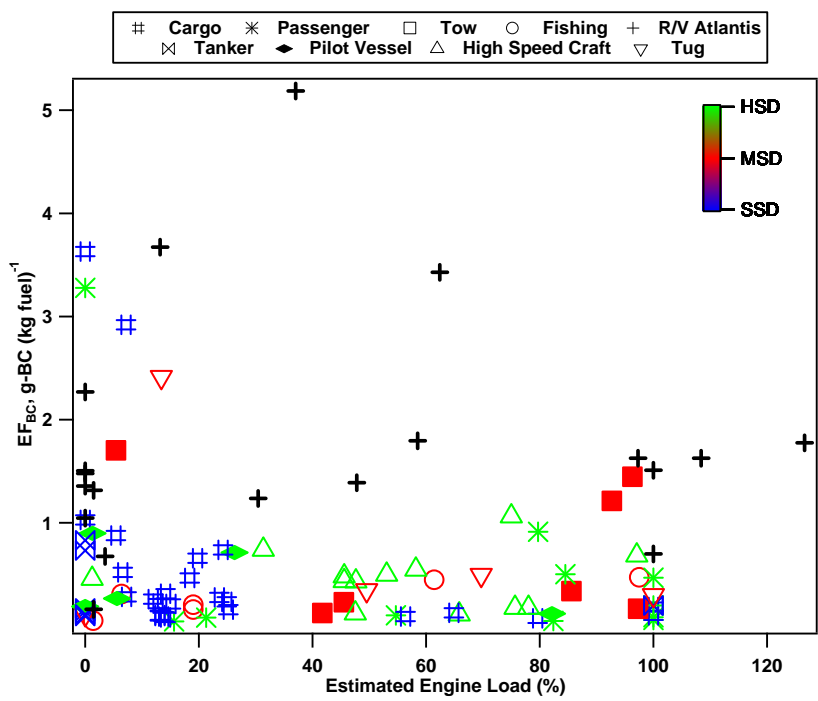

Fig. 6. Individual vessel $\mathrm{EF}_{\mathrm{BC}}$ values as a function of estimated engine load. The markers correspond to ship type and the colours correspond to engine type for individual vessels.

\section{Conclusions}

Black carbon emission factors for over 70 different ships were determined from in situ measurements during the CalNex campaign in summer 2010, off the California coast. The sampled ships were operating on low-sulphur fuels as a result of recently imposed regulations in the area. Four independent methods were used to determine $\mathrm{BC}$ concentrations from which $\mathrm{EF}_{\mathrm{BC}}$ 's for each ship plume sampled were determined: two light absorption techniques (PAS, PSAP), and two incandescent techniques (SP2, SP-AMS). The resulting $\mathrm{EF}_{\mathrm{BC}}$ values from the PAS, PSAP and SP-AMS are in good agreement. However, $\mathrm{EF}_{\mathrm{BC}}$ values from the SP2 were about 2 times smaller than the $\mathrm{EF}_{\mathrm{BC}}$ values from the other three instruments. It is suggested that this is a result of the SP2 measuring $\mathrm{BC}$ particles that exist within only a limited range of $d_{\mathrm{p}, \text { VED }}$ and of contributions to the total BC mass from particles outside this range.

Average $\mathrm{EF}_{\mathrm{BC}}$ 's have been calculated for ships categorized by engine type or vessel type. There is a fair amount of ship-to-ship variability, especially between ships in the HSD and MSD categories. There is no clear indication of any systematic variation in $\mathrm{EF}_{\mathrm{BC}}$ with the vessel engine load that can be discerned from the all-ships ensemble. However, there is some suggestion that $\mathrm{EF}_{\mathrm{BC}}$ decreases with engine load for cargo ship types, but increases with vessel speed for a single research/fishing vessel. The geometric averages between the different engine categories were all similar, with an all-ships average (excluding the R/V Atlantis) of $0.31 \mathrm{~g} \mathrm{BC}(\mathrm{kg} \text { fuel })^{-1}$. Considering the cut average (i.e. that with outliers excluded) the all-ships average was $0.28 \mathrm{~g} \mathrm{BC}(\mathrm{kg} \text { fuel })^{-1}$ with SSD < MSD < HSD. Comparison of the SSD category average, as well as the cargo and tanker vessel type categories individually, with similar measurements from the TexAQS study - where such ship types were typically running on high-sulphur fuels - and more broadly with the published literature indicates that lower $\mathrm{EF}_{\mathrm{BC}}$ 's are obtained when such vessels operate on low-sulphur distillate fuels.

This study substantially increases the number of in-use ships for which $\mathrm{EF}_{\mathrm{BC}}$ values have been directly measured, and provides essential guidance on the quality of various $\mathrm{BC}$ measurement techniques when used to characterize fresh ship emissions. In addition, local and regional assessments of fleet emissions, such as the current study, are essential to refining inventories of ship emissions. While most data currently are derived from single ship and test engine experiments, data collection on an ensemble of ships provides a more robust view of regional fleet behaviour, which is essential for regulatory discussions on ship emissions.

\section{Supplementary material related to this article is available online at http://www.atmos-chem-phys.net/14/ 1881/2014/acp-14-1881-2014-supplement.pdf.}

Acknowledgements. The authors thank the crew of the $\mathrm{R} / \mathrm{V}$ Atlantis, without all of whom this study would not have been possible. This work was supported in part by the US Environmental Protection Agency under a STAR research assistance agreement (RD834558), the NOAA Climate Program (including NA09OAR4310124 and NA09AR4310125), the California Air Resources Board, the Canadian Federal Government (PERD Project C12.007) and NSERC. It has not been formally reviewed by the any of the funding agencies. The views expressed in this document are solely those of the authors, and the funding agencies do not endorse any products or commercial services mentioned in this publication.

Edited by: Y. Cheng

\section{References}

Arnott, W. P., Moosmüller, H., Rogers, F. C., Jin, T., and Bruch, R.: Photoacoustic spectrometer for measuring light absorption by aerosol: instrument description, Atmos. Environ., 33, 28452852, doi:10.1016/S1352-2310(98)00361-6, 1999.

Bates, T. S., Quinn, P. K., Frossard, A. A., Russell, L. M., Hakala, J., Petäjä, T., Kulmala, M., Covert, D. S., Cappa, C. D., Li, S. M., Hayden, K. L., Nuaaman, I., McLaren, R., Massoli, P., Canagaratna, M. R., Onasch, T. B., Sueper, D., Worsnop, D. R., and Keene, W. C.: Measurements of ocean derived aerosol off the coast of California, J. Geophys. Res., 117, D00V15, doi:10.1029/2012jd017588, 2012.

Bond, T. C. and Bergstrom, R. W.: Light Absorption by Carbonaceous Particles: An Investigative Review, Aerosol Sci. Tech., 40, 27-67, doi:10.1080/02786820500421521, 2006. 
Bond, T. C., Anderson, T. L., and Campbell, D.: Calibration and Intercomparison of Filter-Based Measurements of Visible Light Absorption by Aerosols, Aerosol Sci. Tech., 30, 582-600, doi:10.1080/027868299304435, 1999.

Bond, T. C., Streets, D. G., Yarber, K. F., Nelson, S. M., Woo, J.-H., and Klimont, Z.: A technology-based global inventory of black and organic carbon emissions from combustion, J. Geophys. Res., 109, D14203, doi:10.1029/2003jd003697, 2004.

Bond, T. C., Doherty, S. J., Fahey, D. W., Forster, P. M., Berntsen, T., DeAngelo, B. J., Flanner, M. G., Ghan, S., Kärcher, B., Koch, D., Kinne, S., Kondo, Y., Quinn, P. K., Sarofim, M. C., Schultz, M. G., Schulz, M., Venkataraman, C., Zhang, H., Zhang, S., Bellouin, N., Guttikunda, S. K., Hopke, P. K., Jacobson, M. Z., Kaiser, J. W., Klimont, Z., Lohmann, U., Schwarz, J. P., Shindell, D., Storelvmo, T., Warren, S. G., and Zender, C. S.: Bounding the role of black carbon in the climate system: A scientific assessment, J. Geophys. Res., 118, 5380-5552, doi:10.1002/jgrd.50171, 2013.

California Air Resources Board, Final Regulation Order. Fuel Sulfur and Other Operational Requirements for Ocean-Going Vessels Within California Waters and 24 Nautical Miles of the California Baseline, available at: http://www.arb.ca.gov/regact/2011/ ogv11/ogvfro13.pdf (last access: 17 June 2013), 2011a.

California Air Resources Board, Amendments to the regulation to reduce emissions of diesel particulate matter, oxides of nitrogen and other criteria pollutants from in-use-on-road dieselfueled vehicles, available at: http://www.arb.ca.gov/msprog/ onrdiesel/documents/tbfinalreg.pdf (last access: 16 December 2013), 2011 b.

Cappa, C. D., Onasch, T. B., Massoli, P., Worsnop, D. R., Bates, T. S., Cross, E. S., Davidovits, P., Hakala, J., Hayden, K. L., Jobson, B. T., Kolesar, K. R., Lack, D. A., Lerner, B. M., Li, S. M., Mellon, D., Nuaaman, I., Olfert, J. S., Petaja, T., Quinn, P. K., Song, C., Subramanian, R., Williams, E. J., and Zaveri, R. A.: Radiative absorption enhancements due to the mixing state of atmospheric black carbon, Science, 337, 1078-1081, doi:10.1126/science.1223447, 2012.

Cappa, C. D., Williams, E. J., Lack, D. A., Buffaloe, G. M., Coffman, D., Hayden, K. L., Herndon, S. C., Lerner, B. M., Li, S.M., Massoli, P., McLaren, R., Nuaaman, I., Onasch, T. B., and Quinn, P. K.: A case study into the measurement of ship emissions from plume intercepts of the NOAA ship Miller Freeman, Atmos. Chem. Phys., 14, 1337-1352, doi:10.5194/acp-14-13372014, 2014.

CIMAC: Background information on black carbon emissions from large marine and stationary diesel engines - Definition, measurement methods, emission factors and abatement technologies, Frankfurt, Germany, 2012.

Corbett, J. J., Winebrake, J. J., Green, E. H., Kasibhatla, P., Eyring, V., and Lauer, A.: Mortality from ship emissions: A global assessment, Environ. Sci. Technol., 41, 8512-8518, doi:10.1021/es071686z, 2007.

Cross, E. S., Onasch, T. B., Ahern, A., Wrobel, W., Slowik, J. G., Olfert, J., Lack, D. A., Massoli, P., Cappa, C. D., Schwarz, J. P., Spackman, J. R., Fahey, D. W., Sedlacek, A., Trimborn, A., Jayne, J. T., Freedman, A., Williams, L. R., Ng, N. L., Mazzoleni, C., Dubey, M., Brem, B., Kok, G., Subramanian, R., Freitag, S., Clarke, A., Thornhill, D., Marr, L. C., Kolb, C. E., Worsnop, D. R., and Davidovits, P.: Soot Particle Studies - Instrument Inter-
Comparison - Project Overview, Aerosol Sci. Tech., 44, 592611, doi:10.1080/02786826.2010.482113, 2010.

DeCarlo, P. F., Slowik, J. G., Worsnop, D. R., Davidovits, P., and Jimenez, J. L.: Particle Morphology and Density Characterization by Combined Mobility and Aerodynamic Diameter Measurements. Part 1: Theory, Aerosol Sci. Tech., 38, 1185-1205, doi:10.1080/027868290903907, 2004.

DeCarlo, P. F., Kimmel, J. R., Trimborn, A., Northway, M. J., Jayne, J. T., Aiken, A. C., Gonin, M., Fuhrer, K., Horvath, T., Docherty, K. S., Worsnop, D. R., and Jimenez, J. L.: Field-Deployable, High-Resolution, Time-of-Flight Aerosol Mass Spectrometer, Anal. Chem., 78, 8281-8289, doi:10.1021/ac061249n, 2006.

Diesch, J.-M., Drewnick, F., Klimach, T., and Borrmann, S.: Investigation of gaseous and particulate emissions from various marine vessel types measured on the banks of the Elbe in Northern Germany, Atmos. Chem. Phys., 13, 3603-3618, doi:10.5194/acp-133603-2013, 2013.

Eyring, V., Köhler, H. W., van Aardenne, J., and Lauer, A.: Emissions from international shipping: 1 . The last 50 years, J. Geophys. Res., 110, D17305, doi:10.1029/2004jd005619, 2005.

Flanner, M. G., Zender, C. S., Randerson, J. T., and Rasch, P. J.: Present-day climate forcing and response from black carbon in snow, J. Geophys. Res., 112, D11202, doi:10.1029/2006jd008003, 2007.

Fuglestvedt, J., Berntsen, T., Eyring, V., Isaksen, I., Lee, D. S., and Sausen, R.: Shipping Emissions: From Cooling to Warming of Climate - and Reducing Impacts on Health, Environ. Sci. Technol., 43, 9057-9062, doi:10.1021/es901944r, 2009.

Gao, R. S., Schwarz, J. P., Kelly, K. K., Fahey, D. W., Watts, L. A., Thompson, T. L., Spackman, J. R., Slowik, J. G., Cross, E. S., Han, J. H., Davidovits, P., Onasch, T. B., and Worsnop, D. R.: A Novel Method for Estimating LightScattering Properties of Soot Aerosols Using a Modified SingleParticle Soot Photometer, Aerosol Sci. Tech., 41, 125-135, doi:10.1080/02786820601118398, 2007.

IMO: Prevention of Air Pollution from Ships, 2008.

IMO: Proposal to Designate an Emission Control Area for Nitrogen Oxides, Sulphur Oxides and Particulate Matter, IMO MEPC, 2009.

IMO: Report of the Marine Environment Protection Committee on its Sixty-Second Session, IMO MEPC 62, London, 2011.

Janssen, N., Gerlofs-Nijland, M. E., Lanki, T., Salonen, R. O., Flemming, C., Hoek, G., Fischer, P., Brunekreef, B., and Krzyzanowki, M.: Health Effects of Black Carbon, WHO, Copenhagen, 2012.

Khan, M. Y., Giordano, M., Gutierrez, J., Welch, W. A., AsaAwuku, A., Miller, J. W., and Cocker III, D. R.: Benefits of two mitigation strategies for container vessels: cleaner engines and cleaner fuels, Environ. Sci. Technol., 46, 5049-5056, doi:10.1021/es2043646, 2012.

Kondo, Y., Sahu, L., Moteki, N., Khan, F., Takegawa, N., Liu, X., Koike, M., and Miyakawa, T.: Consistency and Traceability of Black Carbon Measurements Made by Laser-Induced Incandescence, Thermal-Optical Transmittance, and Filter-Based Photo-Absorption Techniques, Aerosol Sci. Tech., 45, 295-312, doi:10.1080/02786826.2010.533215, 2011.

Laborde, M., Mertes, P., Zieger, P., Dommen, J., Baltensperger, U., and Gysel, M.: Sensitivity of the Single Particle Soot Photometer 
to different black carbon types, Atmos. Meas. Tech., 5, 10311043, doi:10.5194/amt-5-1031-2012, 2012a.

Laborde, M., Schnaiter, M., Linke, C., Saathoff, H., Naumann, K.H., Möhler, O., Berlenz, S., Wagner, U., Taylor, J. W., Liu, D., Flynn, M., Allan, J. D., Coe, H., Heimerl, K., Dahlkötter, F., Weinzierl, B., Wollny, A. G., Zanatta, M., Cozic, J., Laj, P., Hitzenberger, R., Schwarz, J. P., and Gysel, M.: Single Particle Soot Photometer intercomparison at the AIDA chamber, Atmos. Meas. Tech., 5, 3077-3097, doi:10.5194/amt-5-3077-2012, $2012 b$.

Lack, D. A. and Corbett, J. J.: Black carbon from ships: a review of the effects of ship speed, fuel quality and exhaust gas scrubbing, Atmos. Chem. Phys., 12, 3985-4000, doi:10.5194/acp-12-39852012, 2012.

Lack, D. A., Lovejoy, E. R., Baynard, T., Pettersson, A., and Ravishankara, A. R.: Aerosol Absorption Measurement using Photoacoustic Spectroscopy: Sensitivity, Calibration, and Uncertainty Developments, Aerosol Sci. Tech., 40, 697-708, doi:10.1080/02786820600803917, 2006.

Lack, D., Lerner, B., Granier, C., Baynard, T., Lovejoy, E., Massoli, P., Ravishankara, A. R., and Williams, E.: Light absorbing carbon emissions from commercial shipping, Geophys. Res. Lett., 35, L13815, doi:10.1029/2008g1033906, 2008a.

Lack, D. A., Cappa, C. D., Covert, D. S., Baynard, T., Massoli, P., Sierau, B., Bates, T. S., Quinn, P. K., Lovejoy, E. R., and Ravishankara, A. R.: Bias in Filter-Based Aerosol Light Absorption Measurements Due to Organic Aerosol Loading: Evidence from Ambient Measurements, Aerosol Sci. Tech., 42, 1033-1041, doi:10.1080/02786820802389277, 2008b.

Lack, D. A., Lerner, B., Granier, C., Baynard, T., Lovejoy, E., Massoli, P., Ravishankara, A. R., and Williams, E.: Light absorbing carbon emissions from commercial shipping, Geophys. Res. Lett., 35, L13815, doi:10.1029/2008g1033906, 2008c.

Lack, D. A., Corbett, J. J., Onasch, T., Lerner, B., Massoli, P., Quinn, P. K., Bates, T. S., Covert, D. S., Coffman, D., Sierau, B., Herndon, S., Allan, J., Baynard, T., Lovejoy, E., Ravishankara, A. R., and Williams, E.: Particulate emissions from commercial shipping: Chemical, physical, and optical properties, J. Geophys. Res.-Atmos., 114, D00F04, doi:10.1029/2008jd011300, 2009.

Lack, D. A., Cappa, C. D., Langridge, J., Bahreini, R., Buffaloe, G., Brock, C., Cerully, K., Coffman, D., Hayden, K., Holloway, J., Lerner, B., Massoli, P., Li, S. M., McLaren, R., Middlebrook, A. M., Moore, R., Nenes, A., Nuaaman, I., Onasch, T. B., Peischl, J., Perring, A., Quinn, P. K., Ryerson, T., Schwartz, J. P., Spackman, R., Wofsy, S. C., Worsnop, D., Xiang, B., and Williams, E.: Impact of Fuel Quality Regulation and Speed Reductions on Shipping Emissions: Implications for Climate and Air Quality, Environ. Sci. Technol., 45, 9052-9060, doi:10.1021/es2013424, 2011.

Lack, D. A., Richardson, M. S., Law, D., Langridge, J. M., Cappa, C. D., McLaughlin, R. J., and Murphy, D. M.: Aircraft Instrument for Comprehensive Characterization of Aerosol Optical Properties, Part 2: Black and Brown Carbon Absorption and Absorption Enhancement Measured with Photo Acoustic Spectroscopy, Aerosol Sci. Tech., 46, 555-568, doi:10.1080/02786826.2011.645955, 2012.

Lack, D., Moosmüller, H., McMeeking, G., Chakrabarty, R., and Baumgardner, D.: Characterizing elemental, equivalent black, and refractory black carbon aerosol particles: a review of tech- niques, their limitations and uncertainties, Anal. Bioanal. Chem., 406, 99-122, doi:10.1007/s00216-013-7402-3, 2014.

Liggio, J., Gordon, M., Smallwood, G., Li, S.-M., Stroud, C., Staebler, R., Lu, G., Lee, P., Taylor, B., and Brook, J. R.: Are Emissions of Black Carbon from Gasoline Vehicles Underestimated? Insights from Near and On-Road Measurements, Environ. Sci. Technol., 46, 4819-4828, doi:10.1021/es2033845, 2012.

Liu, P. S. K., Deng, R., Smith, K. A., Williams, L. R., Jayne, J. T., Canagaratna, M. R., Moore, K., Onasch, T. B., Worsnop, D. R., and Deshler, T.: Transmission Efficiency of an Aerodynamic Focusing Lens System: Comparison of Model Calculations and Laboratory Measurements for the Aerodyne Aerosol Mass Spectrometer, Aerosol Sci. Tech., 41, 721-733, doi:10.1080/02786820701422278, 2007.

Onasch, T. B., Trimborn, A., Fortner, E. C., Jayne, J. T., Kok, G. L., Williams, L. R., Davidovits, P., and Worsnop, D. R.: Soot Particle Aerosol Mass Spectrometer: Development, Validation, and Initial Application, Aerosol Sci. Tech., 46, 804-817, doi:10.1080/02786826.2012.663948, 2012.

Parrish, D. D., Trainer, M., Young, V., Goldan, P. D., Kuster, W. C., Jobson, B. T., Fehsenfeld, F. C., Lonneman, W. A., Zika, R. D., Farmer, C. T., Riemer, D. D., and Rodgers, M. O.: Internal consistency tests for evaluation of measurements of anthropogenic hydrocarbons in the troposphere, J. Geophys. Res., 103, 22339, doi:10.1029/98jd01364, 1998.

Petzold, A., Lauer, P., Fritsche, U., Hasselbach, J., Lichtenstern, M., Schlager, H., and Fleischer, F.: Operation of marine diesel engines on biogenic fuels: modification of emissions and resulting climate effects, Environ. Sci. Technol., 45, 10394-10400, doi:10.1021/es2021439, 2011.

Petzold, A., Ogren, J. A., Fiebig, M., Laj, P., Li, S.-M., Baltensperger, U., Holzer-Popp, T., Kinne, S., Pappalardo, G., Sugimoto, N., Wehrli, C., Wiedensohler, A., and Zhang, X.-Y.: Recommendations for reporting "black carbon" measurements, Atmos. Chem. Phys., 13, 8365-8379, doi:10.5194/acp-13-83652013, 2013.

Ramanathan, V. and Carmichael, G.: Global and regional climate changes due to black carbon, Nat. Geosci., 1, 221-227, doi:10.1038/ngeo156, 2008.

Ryerson, T. B., Andrews, A. E., Angevine, W. M., Bates, T. S., Brock, C. A., Cairns, B., Cohen, R. C., Cooper, O. R., de Gouw, J. A., Fehsenfeld, F. C., Ferrare, R. A., Fischer, M. L., Flagan, R. C., Goldstein, A. H., Hair, J. W., Hardesty, R. M., Hostetler, C. A., Jimenez, J. L., Langford, A. O., McCauley, E., McKeen, S. A., Molina, L. T., Nenes, A., Oltmans, S. J., Parrish, D. D., Pederson, J. R., Pierce, R. B., Prather, K., Quinn, P. K., Seinfeld, J. H., Senff, C. J., Sorooshian, A., Stutz, J., Surratt, J. D., Trainer, M., Volkamer, R., Williams, E. J., and Wofsy, S. C.: The 2010 California research at the Nexus of air quality and climate change (CalNex) field study, J. Geophys. Res., 118, 5830-5866, doi:10.1002/jgrd.50331, 2013.

Sahu, L. K., Kondo, Y., Moteki, N., Takegawa, N., Zhao, Y., Cubison, M. J., Jimenez, J. L., Vay, S., Diskin, G. S., Wisthaler, A., Mikoviny, T., Huey, L. G., Weinheimer, A. J., and Knapp, D. J.: Emission characteristics of black carbon in anthropogenic and biomass burning plumes over California during ARCTAS-CARB 2008, J. Geophys. Res.-Atmos., 117, D16302, doi:10.1029/2011JD017401, 2012. 
Sarvi, A., Fogelholm, C.-J., and Zevenhoven, R.: Emissions from large-scale medium-speed diesel engines: 2. Influence of fuel type and operating mode, Fuel Process. Technol., 89, 520-527, doi:10.1016/j.fuproc.2007.10.005, 2008.

Schwarz, J. P., Spackman, J. R., Gao, R. S., Perring, A. E., Cross, E., Onasch, T. B., Ahern, A., Wrobel, W., Davidovits, P., Olfert, J., Dubey, M. K., Mazzoleni, C., and Fahey, D. W.: The Detection Efficiency of the Single Particle Soot Photometer, Aerosol Sci. Tech., 44, 612-628, doi:10.1080/02786826.2010.481298, 2010.

Sheridan, P. J., Arnott, W. P., Ogren, J. A., Andrews, E., Atkinson, D. B., Covert, D. S., Moosmüller, H., Petzold, A., Schmid, B., Strawa, A. W., Varma, R., and Virkkula, A.: The Reno Aerosol Optics Study: An Evaluation of Aerosol Absorption Measurement Methods, Aerosol Sci. Tech., 39, 1-16, doi:10.1080/027868290901891, 2005.

Slowik, J. G., Cross, E. S., Han, J.-H., Davidovits, P., Onasch, T. B., Jayne, J. T., Williams, L. R., Canagaratna, M. R., Worsnop, D. R., Chakrabarty, R. K., Moosmüller, H., Arnott, W. P., Schwarz, J. P., Gao, R.-S., Fahey, D. W., Kok, G. L., and Petzold, A.: An Inter-Comparison of Instruments Measuring Black Carbon Content of Soot Particles, Aerosol Sci. Tech., 41, 295-314, doi:10.1080/02786820701197078, 2007.

Smith, K. R., Jerrett, M., Anderson, H. R., Burnett, R. T., Stone, V., Derwent, R., Atkinson, R. W., Cohen, A., Shonkoff, S. B., Krewski, D., Pope Iii, C. A., Thun, M. J., and Thurston, G.: Public health benefits of strategies to reduce greenhousegas emissions: health implications of short-lived greenhouse pollutants, The Lancet, 374, 2091-2103, doi:10.1016/S01406736(09)61716-5, 2009.
Sydborn, A., Blomberg, A., Parnia, S., Stenfors, N., Sandstrom, T., and Dahlen, S.-E.: Health effects of diesel exhaust emissions, Eur. Respir. J., 17, 733-746, 2001.

US EPA: User's Guide for the Final NONROAD2005 Model, EPA420-R-05-013, Office of Transportation and Air Quality, 2005.

Williams, E. J., Lerner, B. M., Murphy, P. C., Herndon, S. C., and Zahniser, M. S.: Emissions of $\mathrm{NO}_{\mathrm{x}}, \mathrm{SO}_{2}, \mathrm{CO}$, and $\mathrm{HCHO}$ from commercial marine shipping during Texas Air Quality Study (TexAQS) 2006, J. Geophys. Res., 114, D21306, doi:10.1029/2009jd012094, 2009a.

Williams, E. J., Lerner, B. M., Murphy, P. C., Herndon, S. C., and Zahniser, M. S.: Emissions of $\mathrm{NO}_{\mathrm{x}}, \mathrm{SO}_{2}, \mathrm{CO}$, and $\mathrm{HCHO}$ from commercial marine shipping during Texas Air Quality Study (TexAQS) 2006, J. Geophys. Res.-Atmos., 114, D21306, doi:10.1029/2009jd012094, 2009b. 